The Geographical Journal of Nepal

Vol. 14: 41-80, 2021

DOI: https://doi.org/10.3126/gjn.v14i0.35548

Central Department of Geography,

Tribhuvan University, Kathmandu, Nepal

\title{
Assessment of denudation rate and erosion susceptibility in the upper Tamakoshi basin in the higher Himalayas, Nepal
}

\author{
Niroj Timalsina ${ }^{1}$, Motilal Ghimire ${ }^{2 *}$, \\ ${ }^{1} \mathrm{PhD}$, Scholar, Central Department of Geography, Tribhuvan University \\ ${ }^{2}$ Associate Professor, Central Department of Geography, Tribhuvan University \\ "Corresponding author: moti.ghimre@cdg.tu.edu.np
}

Received: 14 November, 2020; Accepted: 30 December, 2020; Published: March 2021

\begin{abstract}
The higher rate of slope erosion in the Himalayan basins is contributing to rapid change in landform in the mountainous terrain, which has caused sedimentation, and inundation downstream. The Tamakoshi basin is a trans-boundary river that originates from Tibet and flows through Dolakha and Ramechap districts before joining the Sapta Koshi river. Few studies exist in Nepal attempting to quantify the erosion rate and susceptibility. However, they are scattered and mainly focus on either rill-sheet erosion or landslide only. Hence, this study attempted to estimate slope erosion by applying the Revised Universal Soil Loss Equation (RUSLE), and soil and debris erosion from landslide (2000-2019). Spatially distributed erosion intensity maps derived from the RUSLE model, as well as index-based landslide susceptibility map, were integrated to capture both running water and gravity erosion processes. The novelty of this research is that it examined the soil erosion rate using a process-based model as well as from the soil or rock displaced by the observed landslides over the last 20 years. The study estimated gross annual erosion by running water of 9.1 million tons/yr, equivalent to the denudation rate of $3.34 \mathrm{~mm} / \mathrm{yr}$. Of these, landslide erosion accounts for 7.6 million ton/ $y r$, i.e., $2.88 \mathrm{~mm} / \mathrm{yr}$, this covers about $84 \%$ of total slope erosion. High landslide and erosion potential areas are associated with high rainfall, steep slopes, scarps, lower segment of valley side slopes, high relief, and highly fractured and deformed parts of high-grade metamorphic rocks, such as gneiss, quartzite, marbles, migmatite, and granitic gneiss.
\end{abstract}

Keywords: RUSLE, slope erosion, landslides, integrated susceptibility map 


\section{Introduction}

Soil and bedrock erosion, i.e., slope erosion, is a primary geomorphic process in the Himalayan watershed, causing soil and rocks loss in mountain slopes and sedimentation in the valleys and lowland plains (Burbank, et al., 2012). The steep slopes, depleted forest cover, unsustainable agricultural practices, intense monsoon rainfall, and active tectonics, make the Himalayan region highly susceptible to slope erosion (Jain, Kumar, and Varghese, 2001).

There exists a wealth of anecdotal information, but quantitative studies on current rates of soil and bedrock erosion in Nepal are still few. Understanding slope erosion and its role in landscape development has been an essential task in geomorphology. Erosion processes are the agents of landform changes both in the short and long run. Nevertheless, they cause land degradation, disruption of land uses and ecology (Schuster and Highland, 2007), and damage to life and property.

In recent decades, the erosion process in Nepalese mountains has intensified due to growing development activities, including haphazard road construction (Leibundgut, et al., 2016; McAdoo, et al., 2018). At this backdrop, quantification of slope erosion and spatially distributed erosion susceptibility map is crucial to prioritize the soil and forest conservation efforts in the upper watershed and provide information for developing hydropower projects, irrigation, and disaster-resilient urban development downstream.

Various studies have estimated the erosion rate in the Himalayas using a broad spectrum of approaches. Thiede, et al. (2004) measured exhumation rates along the Himalayan front in India and found that the highest rates were in the region of highest precipitation. In contrast, others (Burbank, et al., 2003) have suggested that at the time-scale of $10^{5}$ $-10^{6} \mathrm{yr}$, erosion rates in the Himalayas are driven primarily by tectonic rates. Gabet, et al., (2008) measured sediment load and proposed a rapid but intermittent erosion by glaciers in the Marshyangdi watershed of the Himalayas. This glacial erosion balances the more steady erosion in the landslide-dominated southern watersheds such that, over time, the entire region is being eroded at approximately the same rate.

Similarly, Morin, et al. (2018) used doppler current profiler measurements with depth profiles and daily surface samplings of the suspended load to determine sediment flux and erosion rate. Also, some study has estimated the erosion rate using the field measurement techniques (Ghimire, Higaki, and Bhattarai, 2013). Likewise, several studies exist on soil erosion using the Universal Soil Loss Equation model and revised version and landslide susceptibility, but these studies were done individually that lacked 
integration in approach to provide an overall perspective and understanding of erosion of a basin (Shrestha, 1997; Thapa, 2020). Therefore, this study attempts to integrate the results of two different approaches to evaluate and estimate the Himalayan river basin's erosion susceptibility and rate. It intends to bring different approaches together in a common framework and findings, which was not much practiced in the Himalayan terrain study.

GIS and RS based erosion models are being used for assessing soil erosion, among which revised universal soil loss equation (RUSLE) is common worldwide (Angima, et al., 2003; Kouli, Soupios, and Vallianatos, 2009; Ban, Yu, and Jeong, 2016; Teng, et al., 2018; Sigh and Singh, 2020) and Nepal is no exception (Uddin, Martin, and Maharjan, 2018; Bastola, et al., 2019; Chalise and Kumar, 2020; Koirala, et al., 2019; Thapa, 2020). RUSLE is generally efficient to predict the water-induced rill and sheet soil erosion. Soil loss in the Himalayas and tectonically active mountains elsewhere is contributed mainly by mass movement processes (Korup, Densmore, and Schlunegger, 2010; Gabet et al., 2008; Morin et al., 2018) and should consider the erosion due to the mass movement process as well. Mass movement is the down slope movement of the soil and/or rock (Cruden and Varnes, 1996). It is a gravity erosion process that contributes to a huge amount of sediment with or without the action of water and ice (Selby, 1993).

\section{Study area}

The area drained by the Tamakoshi River was selected for the study. It is a tributary basin of the Saptakoshi river basin, which originates from Tibet, China. It extends from $27^{\circ} 48^{\prime} 55^{\prime \prime}$ to $28^{\circ} 19^{\prime} 32^{\prime \prime}$ in the north and from $86^{\circ} 04^{\prime} 41^{\prime \prime}$ to $86^{\circ} 33^{\prime} 26^{\prime \prime}$ in the east. The basin's outlet constitutes the site of the proposed Tamakoshi V Hydro-electricity project, which is a cascade project of the national pride Upper Tamakoshi hydro project. Similarly, other projects are also being constructed or planned. Quite a large population lives in rural and urban areas downstream, which can be affected by the flood, bank erosion, and sedimentation. It is also assumed that sediment load has increased after April 2015 Earthquake and aftershock (max Mw 7.8-6.9) in the basin.

The trans-boundary part (Tibetan Part) of the Upper Tamakoshi basin comprises Neo proterozoic to Eocene sedimentary rocks deposited in the Tethys basin that separated the Indian and Eurasian plates before their collision (Hagen 1968; Dhital, 2015). These rocks are strongly folded and imbricated, weakly metamorphosed. The surface geology of this part is primarily modified by snow and glacier, and frost action. These processes have sculptured the landform. The geology of the southern part of Nepal's basin 
belongs to the Higher Himalayan Tectonic unit of eastern Nepal. Rock mass in this unit characterizes Precambrian high-grade metamorphic rocks such as gneiss, quartzite, marbles, migmatite, and granitic gneiss (Schelling 1987; Basnet and Panthi, 2017). Due to active tectonics, this region is subject to compression and accumulation of energy, which is being released through the rapture of tectonic faults and fractures during earthquakes. As a result, the southern part of the study area has a complex tectonic stress regime. The southern part of the basin's rock mass has three distinct joint sets, including foliation joints (Panthi, 2019). This geological situation indicates a fragile terrain.

About $67 \%$ of the study area is located in Tibet. The Tamakoshi basin extends from the High Mountain to the High Himalayan range, ranging from 1096 to 7315 masl with a total area of $2159.3 \mathrm{~km}^{2}$. Almost $54 \%$ of the basin is located at an elevation higher than 5000masl. The worldclim data showed that the annual average temperature varies from -11.8 to $11.55^{\circ} \mathrm{C}$ (Fick and Hijmans, 2017). However, the temperature recorded in the nearest station at Jiri ranges from -2 to $25^{\circ} \mathrm{C}$ (Shrestha, Bajracharya, and Babel, 2016). Similarly, the annual average rainfall ranges from 249-2454 mm (Fick and Hijmans, 2017), and higher rainfall is concentrated in the river valley in the Nepalese part (Figure-3).

About $80 \%$ of the total land is either covered with snow or barren rocky land. Most of the barren land is covered with snow in winter. Similarly, grassland, shrub/bushes, and forest account for $7.3 \%, 3.7 \%$, and $5.3 \%$, respectively. Only $0.5 \%$ of the land is cultivated, which is localized in the lower part of the basin (Figure-5). Settlements, as well as housing patterns, are scattered in the lower region in Nepal (Figure-1). However, in the upper region, settlements are scattered characterizing traditionally compact spacing of houses to adapt to cold alpine conditions and a fragmented resource base caused by the High Himalayan terrain. Tamang and Sherpas in Nepal, and Tibetans in the Chinese part are the major ethnic groups adhering to Tibetan Buddhism traditions living in this basin. These people are engaged in agro-pastoral farming as well as partly in tourism and trading activities. In this connection, this study attempts to estimate the slope erosion rate and produce a spatially distributed erosion susceptibility map of the area, where human intervention is comparatively low. However, the sediments yield from this basin could impact development projects and human life and activities downstream. 


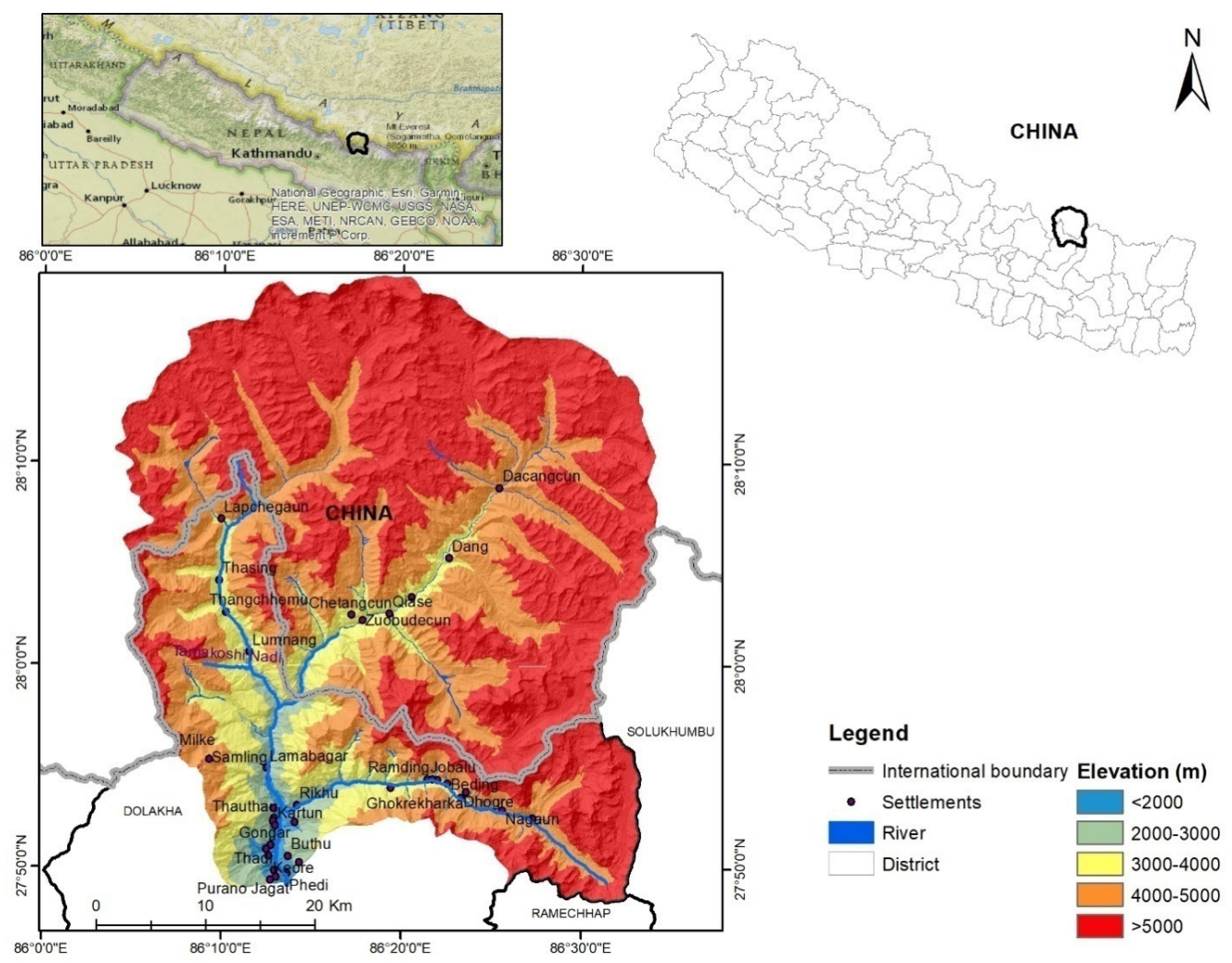

Figure 1: Location map of the Tamakoshi basin showing with altitudinal distribution

\section{Methods and materials}

\section{Rationale of models and a short review}

The basic underlying principle of determining soil and landslide erosion and susceptibility of the terrain is that these processes do not occur randomly or by chance (Crozier, 1986; Guzzetti et al., 1999). Slope failures and erosion in space and time are the results of the strength and interplay of physical processes and mechanical laws against the controlling and triggering factors, which determine erosivity, erodibility, stability, or failure of a slope (Aleotti and Chowdhury, 1999; Varnes, 1984; Wischmeier and Smith, 1978; Selby 1993; Ghimire and Timalsina, 2020). These physical phenomena, which control the incidences and intensity of erosion and landslide occurrence in various sizes and types in space and time, can be modeled to determine erosion and landslide susceptibility. Numerous processes based on physical soil erosion models are developed for predicting soil erosion. These models represent detachment, transport, and deposition processes. 
A few popular such models are USLE (Wischmeier and Smith, 1978); RUSLE (Renard et al., 1991); SWAT (Arnold et al., 1998); WEPP (Nearing, Ascough, \& Chaves, 1989); EUROSEM (Morgan, et al., 1998) and others. The recent trend of publication using soil erosion models indicates that researchers rely on erosion models' capacity to estimate soil loss rates and sediment yields and simulate erosion responses to land use and climate change (Batista, et al., 2019). However, various studies have evaluated that un-calibrated erosion models' predictive accuracy is often limited (de Vente et al., 2013; Jetten, de Roo, and Favis-Mortlock, 1999; Van Rompaey et al., 2003). Still, these erosion models with calibration or customized to local biophysical conditions are applied to influence decision-making in matters of erosion control and watershed management. Erosion contributed by landslides in the Himalayas have done recently by several authors have reaffirmed that throughout the Himalayas, mass wasting is the dominant erosional processes on hill slopes and the main source of sediment to rivers (Burbank et al., 1996; Hovius et al., 1997; Densmore and Hovius, 2000; Gabet et al., 2004; Struck, et al., 2015; Morin et al., 2018; Marc et al., 2019). Erosion studies carried out on the mountains, undermining landslides' erosion will only reflect the partial state of the erosion. Hence, the estimation of erosion through the volume of soil and bedrock loss from the inventory landslides needs to be integrated with the RUSLE erosion map. Similarly, several deterministic or statistical models are increasingly used for landslide susceptibility assessment in recent times (Felicísimo et al., 2013). Deterministic models are process-based, which rely on the geotechnical property of slope, soil, lithology, and subsurface hydrology that either represents driving or resisting force (Montgomery and Dietrich, 1994; Formetta et al., 2016). The result is more accurate and predictive, but surveyed data usually is not available, and field data collection is expensive and takes time to assess spatially distributed susceptibility over a large region.

Statistical models are based on evidence represented by landslide occurrences (Van Westen, 1997; Ghimire et al., 2001; Reichenbach, et al., 2018), which are related to causative geo-environmental factors, whose layers can be generated from maps and imageries. The weights for these factors are assigned based on statistically calculated values. Weight of evidence, frequency ratio, or multivariate statistics are popularly used statistical models in determining landslide susceptibility. In the absence of geotechnical data, this approach is a better alternative, as they have provided reliable results with easily available data (Eeckhaut et al., 2012; Piacentini et al., 2012; Cui, Lu, \& Li, 2017; Van Westen, 2000; Ghimire et al., 2011). 


\section{Materials and methods}

Estimation of slope erosion and susceptibility assessment was done by three-step approaches. The first step is represented by the RUSLE model which estimates spatially distributed surface erosion. The second approach is the estimation of soil and bedrock loss from the inventoried landslides and landslide susceptibility assessment. The third step is the integration of RUSLE erosion map with the landslide susceptibility map to produce an integrated slope erosion map.

GIS \& RS technology was applied to generate the layers representing the factors determining erosion and influencing the terrain's susceptibility. GIS-based RUSLE model and statistically derived landslide index are the main tools used in the study.

The overall methodology adopted in the study is summarized in Figure 2.

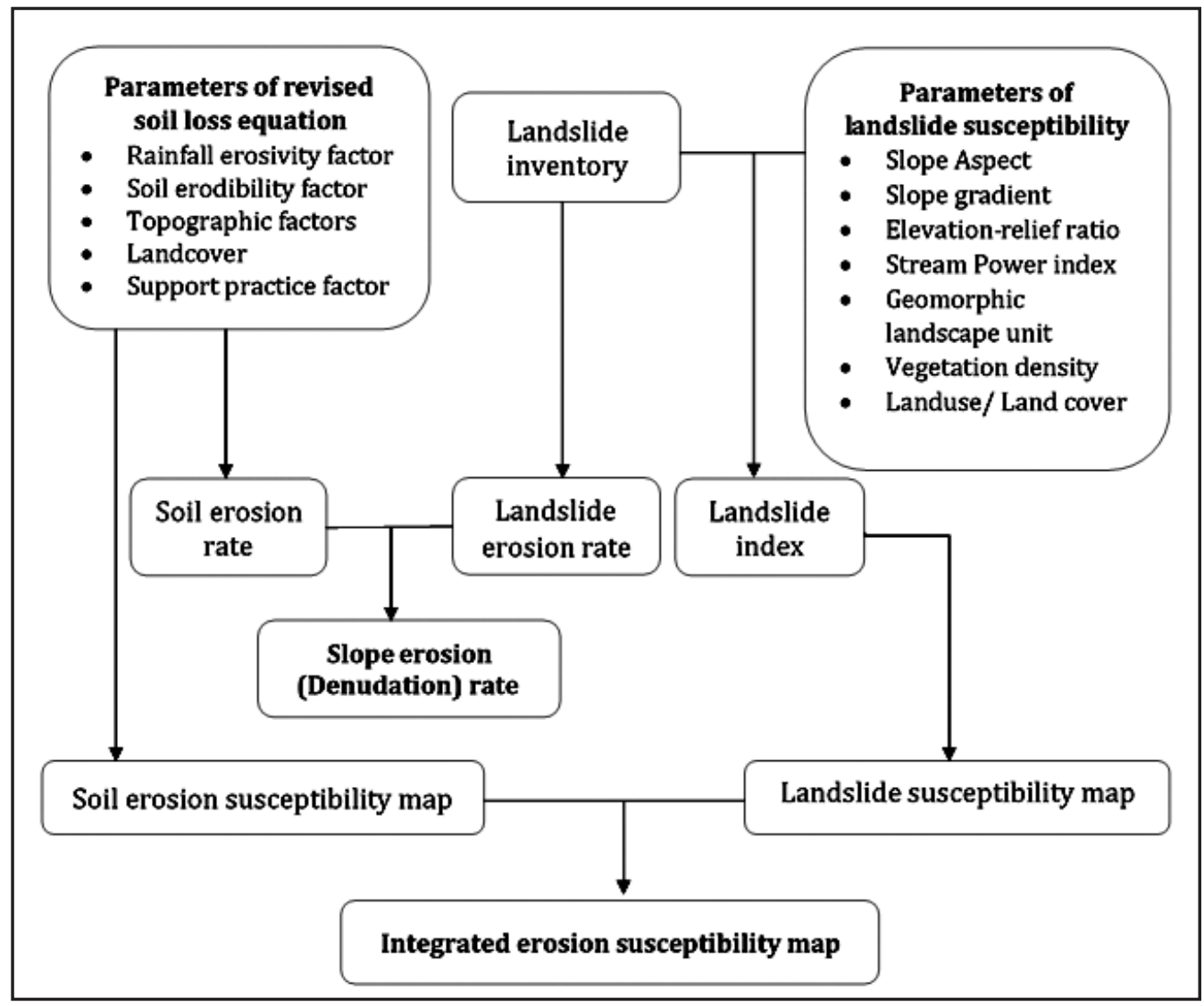

Figure 2: Flow charts showing the method adopted in the study. 


\section{RUSLE model}

Several empirical models have been developed for estimating soil erosion in watersheds; among these, the most used during the past 30 years is the Universal Soil Loss Equation (USLE). Its revised version, i.e., Revised Universal Soil Loss Equation (RUSLE), has been employed in this study. The RUSLE is an empirical model for the prediction of the long-term average annual rate of soil erosion (expressed in tons/ha/ yr), by combining several factors having a bearing on the erosion rate, namely; rainfall erosivity, soil erodibility, steepness and length of the slope (topography), vegetation cover and conservation support practices. The input parameters were generated in the GIS platform in various thematic maps used in equation (1) (Figure-5) (Renard et al., 1997).

$\mathrm{A}=\mathrm{R} * \mathrm{~K} * \mathrm{LS} * \mathrm{C} * \mathrm{P}$

Where A: computed annual soil loss per unit area [ton/ha/year]

$\mathrm{R}$ : Rainfall erosivity factor, an erosion index for the given storm period in [MJ $\mathrm{mm} \cdot \mathrm{ha}-1 \cdot \mathrm{hr}^{-1} \cdot$ year $\left.^{-1}\right]$

K: Soil erodibility factor

LS: Topographic factors

C: Cover-management factor-ratio of soil loss P: Support practice factor-ratio of soil loss with a support practice contour tillage, strip cropping, terracing to soil loss with row tillage parallel to the slope.

Rainfall erosivity factor $(\mathbf{R})$ : The rainfall-runoff erosive factor, $R$, is calculated from the following relationship (Morgan, 1984):

$\square=79+0.363 \square$

Where $\mathrm{p}$ is the average annual rainfall, $\mathrm{mm}$. The annual rainfall was obtained from the WorldClim database that provided $1 \mathrm{~km}$ spatial resolution climatic data (Fick and Hijmans, 2017). The study area's average annual rainfall ranges from249-2454 mm (Figure-3). 


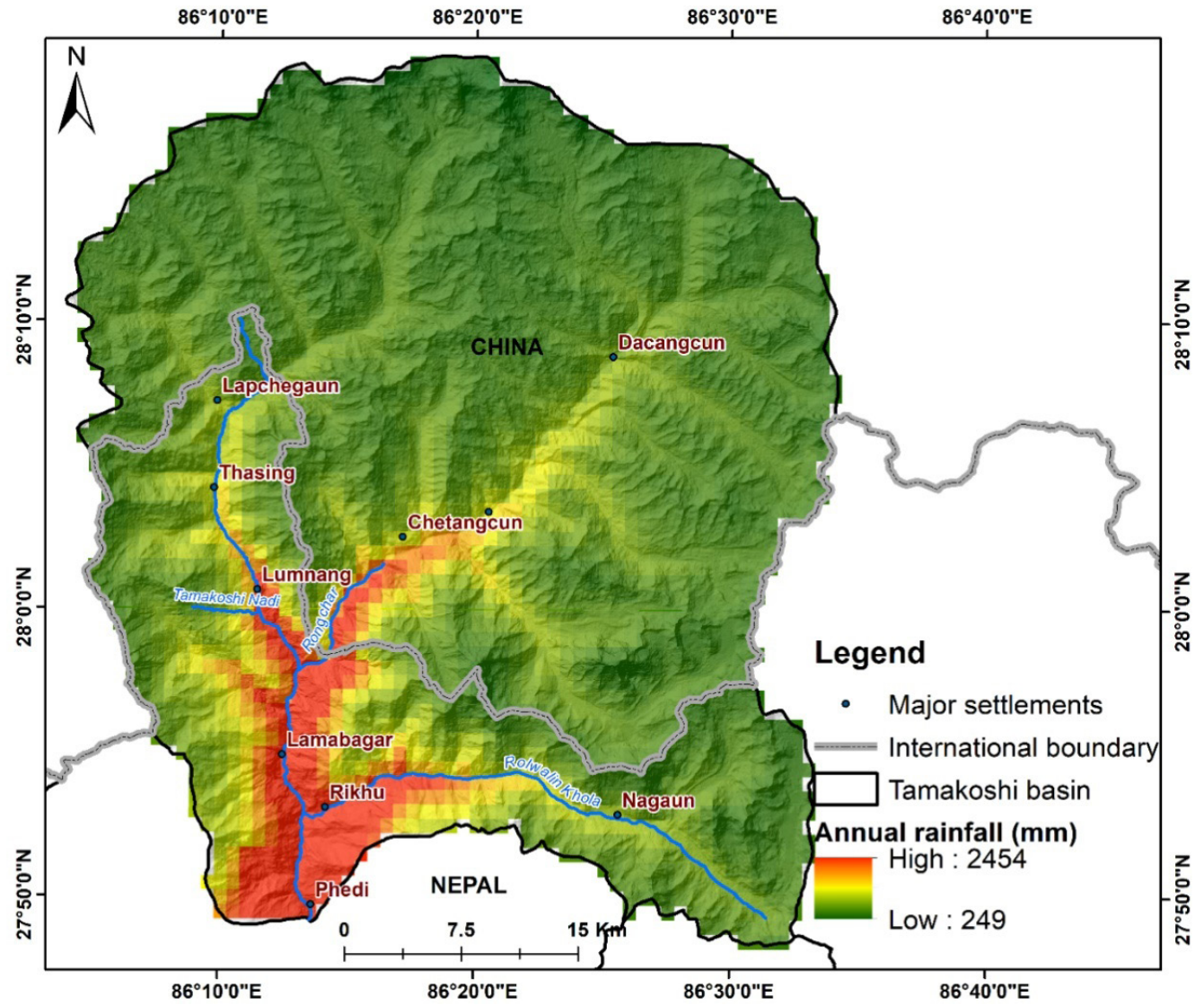

Figure 3: Rainfall distribution in study area

Soil erodibility factor (K): The soil erodibility factor $\mathrm{K}$ is a measure of erodibility for a standard condition. Since soil erodibility factor K represents soil's susceptibility to erosion and the amount and rate due to runoff effect. Soil data of study area for both Nepal and China were obtained from the Soil and Terrain Database (SOTER), compiled and prepared by World Food Organization (FAO) (Figure-4).Similarly, K factors were initially extracted from the monograph published by the US Department of Agriculture (USDA, 2000) with necessary modification referring to the past studies on similar mountain regions (Gardner and Gerrard, 2003; Maqsoom et al., 2020; Veeranarayana, Raju and Wuletaw, 2019) (Table 1). 


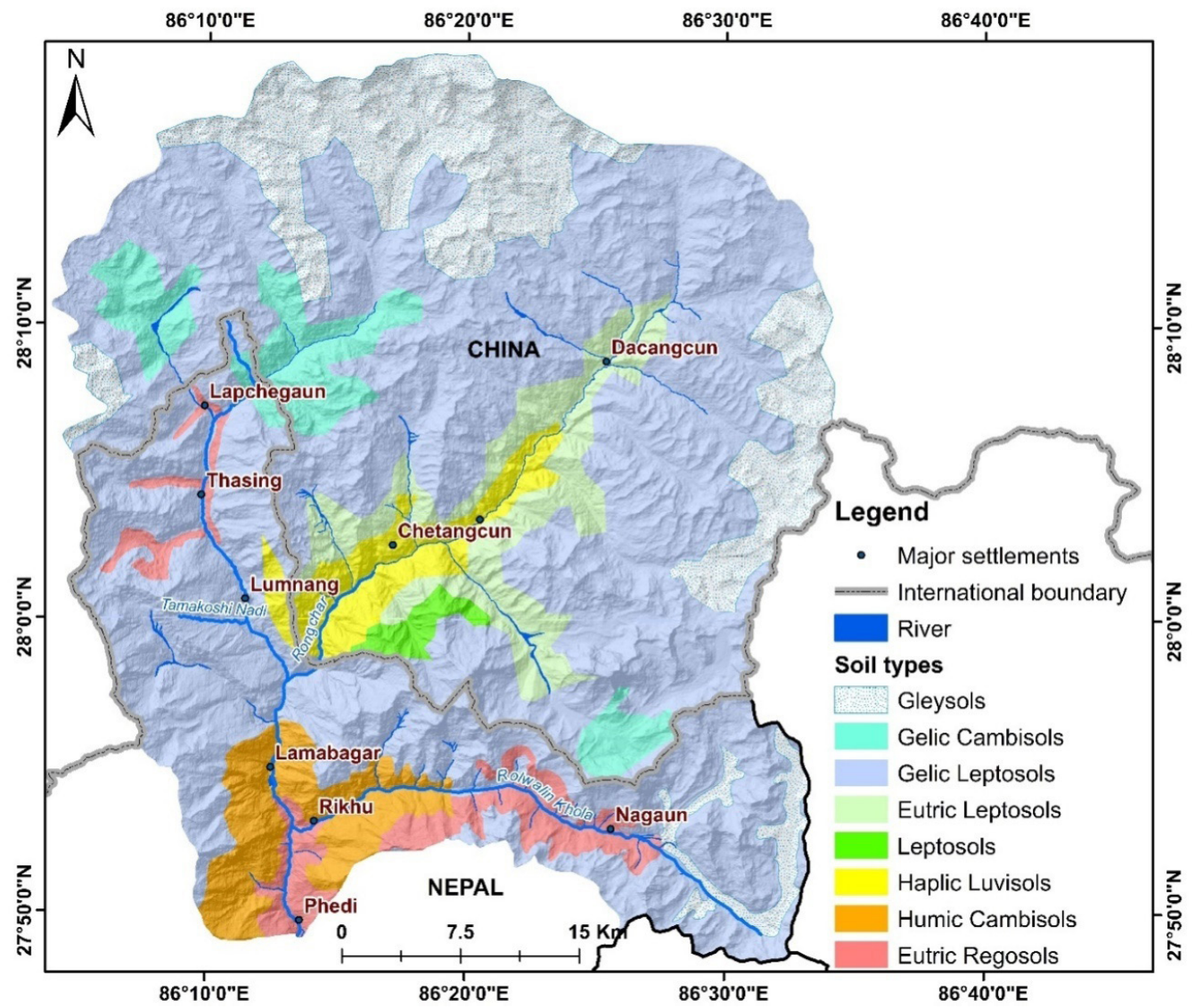

Figure 4: Soil types in study area

\section{Table 1: Distribution of $K$ factors on soil types}

\begin{tabular}{|c|c|c|c|c|}
\hline $\begin{array}{l}\text { Soil types } \\
\text { (FAO } \\
\text { system) }\end{array}$ & Subunits & Characteristics & $\begin{array}{l}\text { K (tons } \\
\text { ha h h ha } \\
\left.\mathbf{M J}^{-1} \mathbf{m m}^{-1}\right)\end{array}$ & \begin{tabular}{|l} 
Justification for K \\
value
\end{tabular} \\
\hline \multirow[t]{2}{*}{ Leptosols } & \begin{tabular}{|l} 
Eutric \\
Leptosols
\end{tabular} & $\begin{array}{l}\text { Strongly, gravelly, } \\
\text { and/or stony and has } \\
\text { formed a relatively } \\
\text { deeper horizon then } \\
\text { Gelic Leptosols }\end{array}$ & 0.34 & $\begin{array}{l}\text { Low vegetation } \\
\text { cover owing to the } \\
\text { limited thickness of } \\
\text { the soil, exposed the } \\
\text { soil for erosion }\end{array}$ \\
\hline & \begin{tabular}{|l} 
Gelic \\
Leptosols
\end{tabular} & $\begin{array}{l}\text { Soils have a shallow } \\
\text { layer over the bedrock } \\
\text { and generally covered } \\
\text { with snow }\end{array}$ & 0.26 & $\begin{array}{l}\text { This thin layered soil } \\
\text { on the rocks of the } \\
\text { alpine area favors } \\
\text { low erodibility }\end{array}$ \\
\hline
\end{tabular}




\begin{tabular}{|c|c|c|c|c|}
\hline $\begin{array}{l}\text { Soil types } \\
\text { (FAO } \\
\text { system) }\end{array}$ & Subunits & Characteristics & $\begin{array}{l}\text { K (tons } \\
\text { ha h ha }^{-1} \\
\mathbf{M J}^{-1} \mathbf{m m}^{-1} \text { ) }\end{array}$ & $\begin{array}{l}\text { Justification for K } \\
\text { value }\end{array}$ \\
\hline \multicolumn{2}{|l|}{ Gleysols } & $\begin{array}{l}\text { Soils are formed under } \\
\text { waterlogged conditions } \\
\text { and closely associated } \\
\text { with the glacier in the } \\
\text { study area }\end{array}$ & 0.2 & $\begin{array}{l}\text { Soil particles } \\
\text { normally stick } \\
\text { together in frozen } \\
\text { soil and thus are } \\
\text { more resistant to } \\
\text { erosion }\end{array}$ \\
\hline \multirow[t]{2}{*}{ Cambisols } & $\begin{array}{l}\text { Gelic } \\
\text { Cambisols }\end{array}$ & $\begin{array}{l}\text { Found in semi humid } \\
\text { and/or partially } \\
\text { humid on sub-alpine } \\
\text { to alpine regions } \\
\text { with sub percolative } \\
\text { hydrological regime } \\
\text { (Goryachkin \& } \\
\text { Targulian, 1990) }\end{array}$ & 0.25 & $\begin{array}{l}\text { A moderate rate of } \\
\text { erosion is expected } \\
\text { as soils contain } \\
\text { some silt and sand } \\
\text { fractions }\end{array}$ \\
\hline & $\begin{array}{l}\text { Humic } \\
\text { Cambisols }\end{array}$ & $\begin{array}{l}\text { Composed of medium } \\
\text { to fine-textured } \\
\text { materials derived from } \\
\text { a wide range of rocks, } \\
\text { mostly in alluvial, } \\
\text { colluvial and aeolian } \\
\text { deposits (FAO, 2015) }\end{array}$ & 0.48 & $\begin{array}{l}\text { A higher rate of } \\
\text { erosion is expected } \\
\text { as agriculture is } \\
\text { practiced the steep } \\
\text { terraces in the study } \\
\text { area }\end{array}$ \\
\hline Regosols & \begin{tabular}{|l} 
Eutric \\
Regosols
\end{tabular} & $\begin{array}{l}\text { Very weakly } \\
\text { developed mineral } \\
\text { soils in unconsolidated } \\
\text { materials (ISRIC, } \\
\text { 2020b) }\end{array}$ & 0.5 & $\begin{array}{l}\text { Regosols are well } \\
\text { recognized for their } \\
\text { high erodibility in } \\
\text { mountainous terrain }\end{array}$ \\
\hline Luvisols & \begin{tabular}{|l} 
Haplic \\
Luvisols
\end{tabular} & $\begin{array}{l}\text { Higher clay content } \\
\text { and composed of } \\
\text { unconsolidated } \\
\text { materials including } \\
\text { glacial till, and } \\
\text { aeolian, alluvial and } \\
\text { colluvial deposits } \\
\text { (FAO, 2015) }\end{array}$ & 0.35 & $\begin{array}{l}\text { Luvisols in the study } \\
\text { area is having a high } \\
\text { silt content, which } \\
\text { may be affected by } \\
\text { a moderate rainfall } \\
\text { and, therefore, are } \\
\text { vulnerable to soil } \\
\text { erosion }\end{array}$ \\
\hline
\end{tabular}

Topographic factors (LS): The topographical factor constitutes two factors named slope length (L) and slope steepness (S). Slope length (L) is the effect of slope length on erosion. The slope length is a function of flow accumulation that is defined as the distance from the point of origin of overland flow to the point where either the slope decreases to the extent that deposition begins or runoff water enters a well-defined channel. Slope steepness (S) represents the effect of slope steepness on erosion (Smith 
and Wischmeier, 1957). The effects of slope steepness have a greater impact on soil loss than slope length. Steeper the slope, the greater is the erosion. Thus, the LS is calculated as (Ganasri and Ramesh, 2016):

$$
L S=\left(\frac{Q a M}{22.13}\right)^{y} *\left(0.065=0.045 * S g+0.005 * S g^{\wedge} 2\right)
$$

Where, $\mathrm{LS}=$ Topographical factor; $\mathrm{Qa}=$ Flow Accumulation grid; $\mathrm{Sg}=$ Grid slope in percentage; $\mathrm{M}=$ Grid size ( $\mathrm{x}$ X y), $\mathrm{y}=$ dimensionless exponent which depends on slope steepness, being 0.5 for slopes exceeding $4.5 \%, 0.4$ for $3-4.5 \%$ slopes, 0.3 for $1-3 \%$, and 0.2 for slopes less than 1\% (Wischmeier and Smith, 1978). Topographic slope factor (SL) was computed from Shuttle Radar Topographic Mission (SRTM) digital elevation model (DEM) having $30 \mathrm{~m}$ resolution.

Land cover: Land cover was derived from Google Earth image of 2018-2019 depending upon the quality of the image and cloud cover condition. Land cover classes were visually interpreted using interpretation keys such as tone, color, texture, pattern, shape, size, and association.

The land cover factor, $C$, affects the erosion rate through vegetation cover, cropping, and management practices. Table- 2 summarizes the $\mathrm{C}$ factor for the different land cover classes, which is assigned according to Koirala, et al., 2019. However, C factor for snow was assigned as 0.2 as snow-covered parts in the basin experience seasonal freezing and melting processes that trigger soil erosion. This erosion can also be attributed to seasonally thawed soils by snow- and ice-melting runoff in the study basin's high altitude (Ban et al., 2016).

Table 2: Land cover and their $\mathrm{C}$ factors

\begin{tabular}{|l|l|l|l|}
\hline Land cover & Area $\mathbf{( S q}$ Km) & Percentage (\%) & C Factor \\
\hline Barren land & 467.5 & 21.7 & 0.45 \\
\hline Built-up area & 0.3 & 0.0 & 0.001 \\
\hline Cultivated land & 10.0 & 0.5 & 0.21 \\
\hline Forest & 115.2 & 5.3 & 0.01 \\
\hline Glacier \& Moraine & 153.6 & 7.1 & 0.01 \\
\hline Grassland & 156.9 & 7.3 & 0.03 \\
\hline Lake & 14.2 & 0.7 & 0.001 \\
\hline River \& riverbed & 11.1 & 0.5 & 1 \\
\hline Shrub/bushes & 79.8 & 3.7 & 0.03 \\
\hline Snow & 1150.6 & 53.3 & 0.2 \\
\hline
\end{tabular}




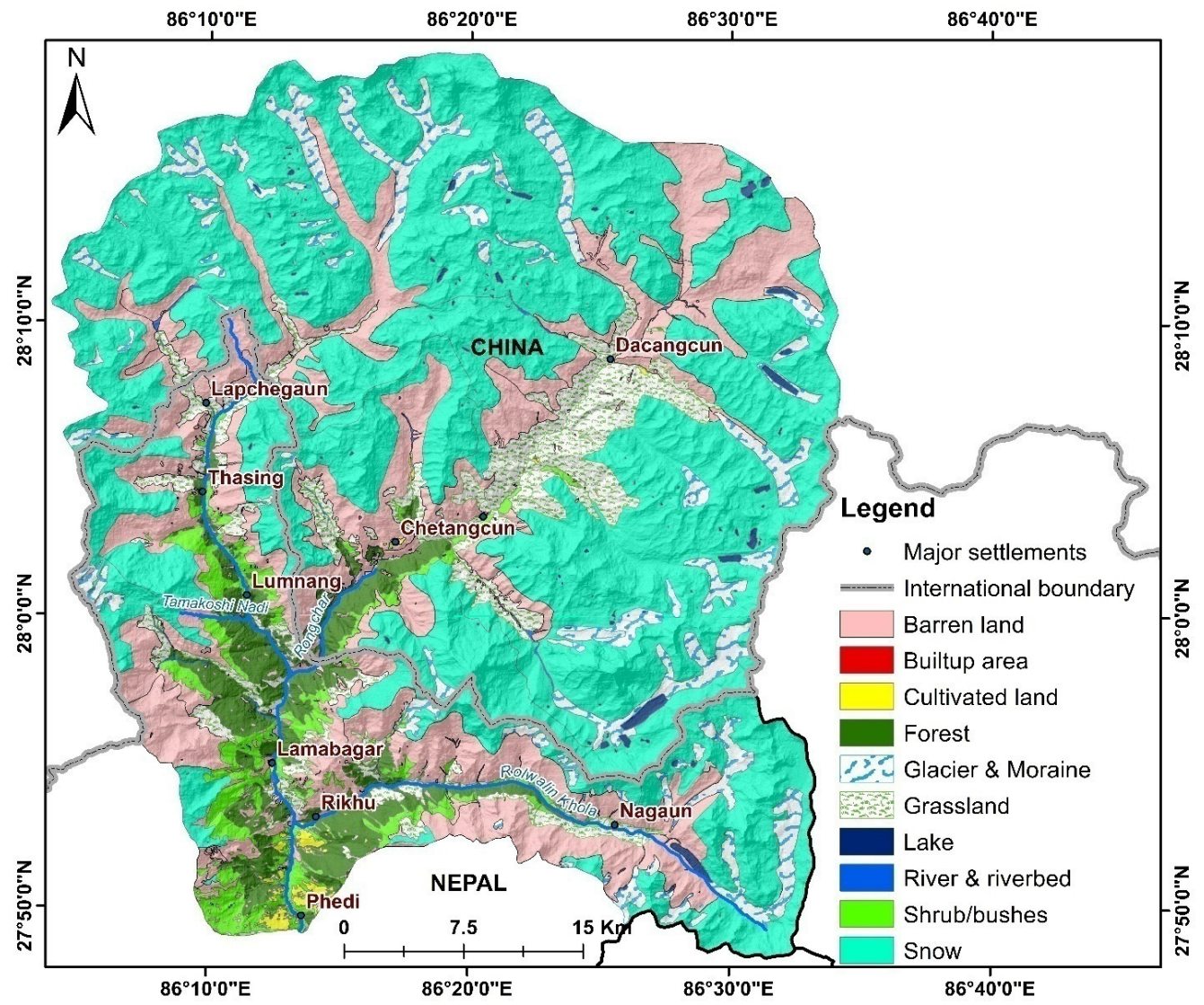

Figure 5: Land cover (2019), Upper Tamakoshi basin

Support practice factor (P): $\mathrm{P}$ factor accounts for control practices that reduce the erosion potential of runoff by their influence on drainage patterns, runoff concentration, runoff velocity, and hydraulic forces exerted by the runoff on the soil surface (Renard et al., 1991). In the present study, no information concerning such practices is available. Hence, the $\mathrm{P}$ factor was assigned a value equal to 1 throughout the watershed area by assuming that virtually no conservation measures are taken.

\section{Estimation of slope erosion rate}

The overall slope erosion rate was estimated by summing up the RUSLE's erosion model and the landslide evacuated soil and rock debris mass.

Total slope erosion $=$ RUSLE soil loss + Soil and bedrock erosion from landslide 
The RUSLE estimates the total mass of the soil erosion, which is converted into a volume using the equation:

Mass $(\mathrm{Kg})=$ Volume $\left(\mathrm{m}^{3}\right) /$ Density $\left(\mathrm{Kg} / \mathrm{m}^{3}\right)$, where, Mass $=$ RUSLE soil loss in $\mathrm{Kg} \&$ Density $=$ Soil density of landslide $=1260 \mathrm{Kg} / \mathrm{m}^{3}($ Yang \& Gao, 2018)

Similarly, the volume of soil and rock debris evacuated by landslide events was used to estimate the erosion rate from landslide between 2000 - 2019. Landslides were classified into shallow or bedrock types depending on their material, mechanism of failure, and dimension. Subsequently, scars of the landslide were converted into a volume using the formula (Larsen, et.al, 2010):

$V=\alpha A^{\#}$, where, $\mathrm{V}=$ Volume of landslide $\left(\mathrm{m}^{3}\right)$ and $\alpha A=$ Area of individual landslide $\operatorname{scar}\left(\mathrm{m}^{2}\right)$

\section{For shallow landslide:}

$\log 10 \alpha=-0.649 \pm 0.021 \& ¥=1.262 \pm 0.009$

\section{For bed rock landslide}

$\log 10 \alpha=-0.63 \pm 0.06 \& ¥=1.41 \pm 0.02$

Finally, denudation rate is evaluated as Erosion rate $=$ Volume/Total area of basin and reflect in $\mathrm{mm} / \mathrm{yr}$.

\section{Landslide susceptible assessment}

\section{Landslide inventory}

Inventory of landslide is the first step to analyze the landslide susceptibility, and this was performed from the Google Earth images of the years between 2000-2019 and LANDSAT 8 images. Altogether 262 landslides were inventoried, including shallow and bedrock slides, with total coverage of 1237.5 ha (Table 3). Subsequently, inventoried landslides were segregated into pre-and post-situation of the 2015 April earthquake (Figure-6). 
Table 3: Landslide distribution in the Tamakoshi basin

\begin{tabular}{|l|l|l|l|l|l|l|l|}
\hline \multirow{2}{*}{$\begin{array}{l}\text { Inventoried } \\
\text { landslide }\end{array}$} & \multicolumn{2}{l|}{ Number of landslides } & \multicolumn{2}{l|}{ Area in ha } \\
\cline { 2 - 8 } & Shallow & Bedrock & Total & $\begin{array}{l}\text { Total area } \\
\text { (ha) }\end{array}$ & Minimum & Maximum & Mean \\
\hline $\begin{array}{l}\text { Before } \\
\text { earthquake } \\
(2000-2014)\end{array}$ & 114 & 25 & 139 & 838.2 & 0.23 & 104.5 & $6.03 \pm 11.02$ \\
\hline $\begin{array}{l}\text { After } \\
\text { earthquake } \\
(2015-2019)\end{array}$ & 111 & 12 & 123 & 399.4 & 0.04 & 49.9 & $3.25 \pm 6.8$ \\
\hline Total & 225 & 37 & 262 & 1237.5 & 0.04 & 104.5 & $4.7 \pm 9.4$ \\
\hline
\end{tabular}

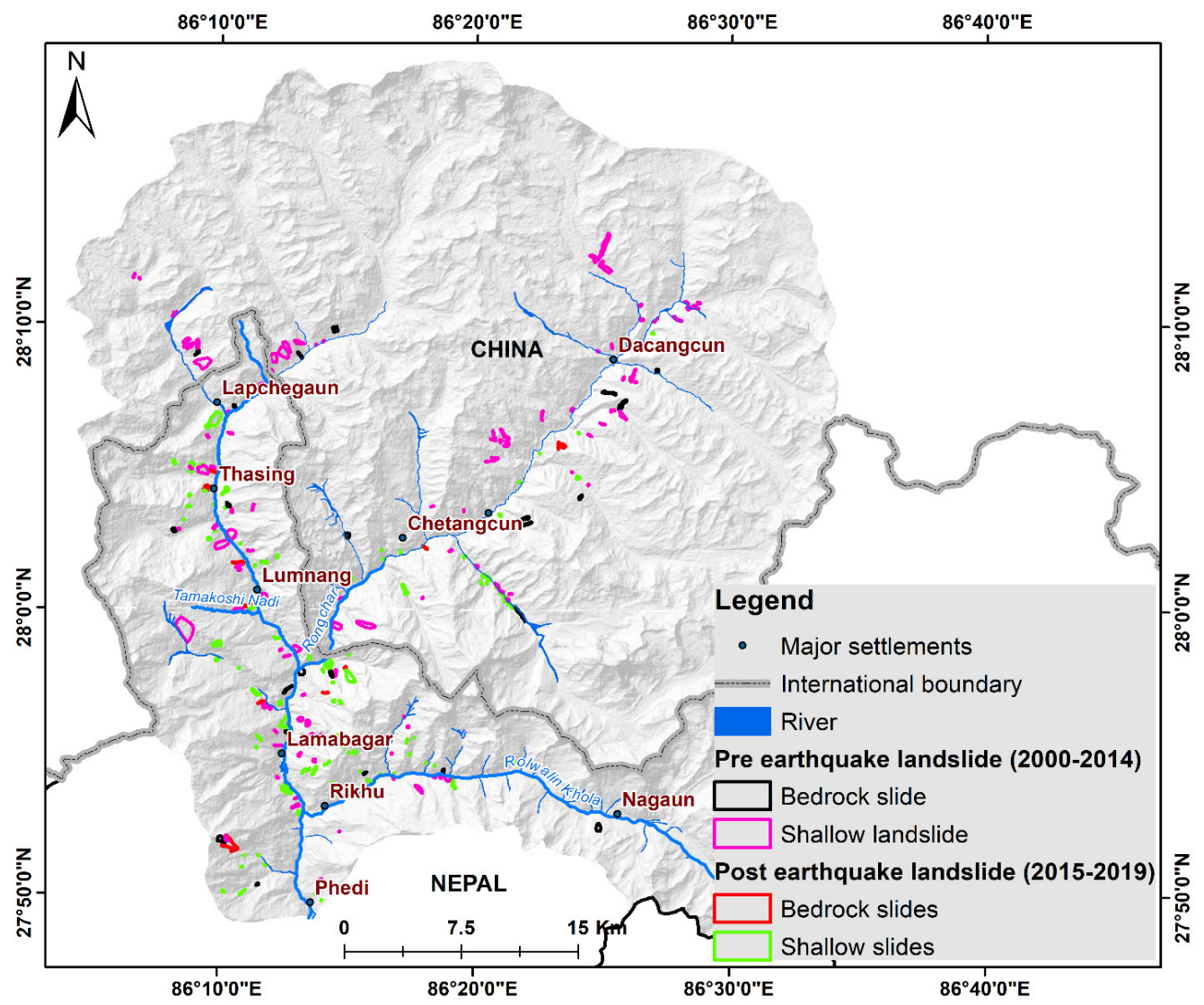

Figure 6: Distribution of landslide in pre-post April 2015 earthquake

Before the April-2015 earthquake, debris flow was the dominant failure type, followed by rock fall and cliff erosion. More than $80 \%$ of such debris flow were shallow types. The other landslides include typical landslides such as debris slides, complex slides, 
wedge failure, slump, shallow landslides, river undercut failures. Widespread rocky cliff and steep slopes exposed to frost action and weathering trigger rock fall and cliff erosion, debris flow, avalanche or slides. Many debris flows in higher altitudes seem to originate from snow-melt water carrying a massive load of debris. Typically steep slopes, scarps, high relief, and toe slopes dominated the location of landslides, which indicate past earthquake failures, river incision in addition to rainfall effect.

Post-earthquake landslide inventory revealed the higher occurrence of rock fall or rockslides, debris flow, which originated from the upper slopes as compared to other types of failures were detected. Post-earthquake landslides are primarily located on high scarp slopes close to sharp ridgelines, slope breaks, and steep V-shaped slopes. Many debris flows seem to originate from the colluvialor earlier landslide deposits stored at the slope-breaks. Many landslides evolved into channelized debris flow on the slopes.

Although the post-earthquake landslides are small in size, their numbers are quite greater than the pre-earthquake situation. This indicates that episodic events like earthquake increase the susceptibility of terrain to widespread shallow to moderate landslides events. These landslide events have contributed to a large amount of sediment load in the Tamakoshi River. A perceptible rise in siltation was seen close to the Tamakoshi Hydropower Project. Hence, the integration of a landslide susceptibility map to evaluate soil erosion in the basin becomes relevant and justified.

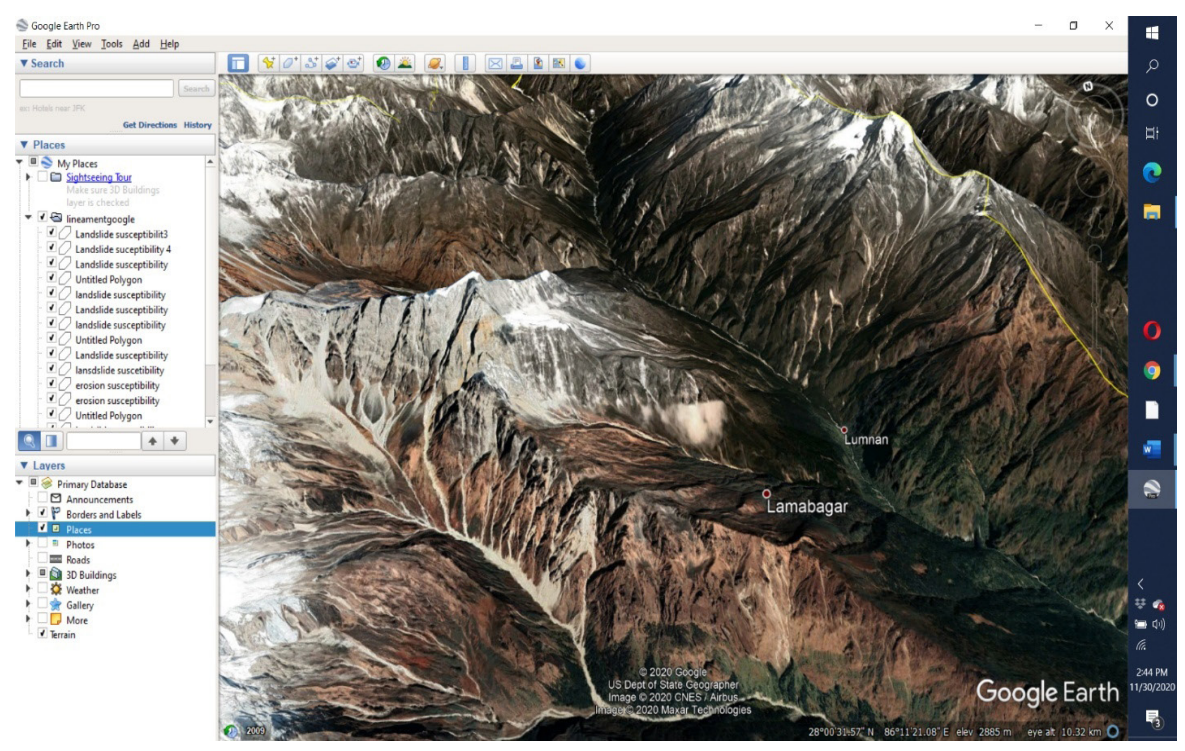

Figure 7: Post-earthquake landslide scars seen on imageries covering the southern part of the basin 


\section{Landslide susceptibility index}

Landslide susceptibility is the likelihood of a landslide occurring in an area based on local terrain conditions (Brabb, 1985). It predicts "where" landslides are likely to occur (Guzzetti et al., 2005).

Landslide index, a bivariate technique, is used to evaluate the landslide susceptibility. For this, seven landslide influencing parameters were prepared in the ArcGIS environment (Table-4).

Table 4: Landslide susceptibility mapping parameters and their justification

\begin{tabular}{|l|l|}
\hline \multicolumn{1}{|c|}{ Parameters } & Descriptions \& Justifications \\
\hline Slope Aspect & $\begin{array}{l}\text { Aspect plays an important role in controlling landslides' spatial } \\
\text { distributions by influencing several factors such as radiation } \\
\text { intensity, soil temperatures, and humid conditions. In some } \\
\text { cases, aspect effects on triggering landslide by intense wetting } \\
\text { and drying cycles. }\end{array}$ \\
\hline Slope gradient & $\begin{array}{l}\text { Slopes in combination with the slope material cohesion, angle } \\
\text { of repose, and moisture conditions normally determine slope } \\
\text { stability conditions. It is a very important parameter in the } \\
\text { slope stability analysis, and it is frequently used in preparing } \\
\text { landslide susceptibility maps (Pradhan and Kim, 2014; Nepal } \\
\text { et al., 2019; Shrestha, Kang and Choi, 2019). }\end{array}$ \\
\hline Elevation-relief ratio & $\begin{array}{l}\text { The elevation-relief ratio is defined as mean elevation minus } \\
\text { minimum elevation divided by relief. This variable can } \\
\text { capture the overall morphology of an area, which is also good } \\
\text { descriptors of landslide terrain (Carrara, 1983; Carrara et al., } \\
\text { 1995; Pachauri, Gupta, and Chander, 1998; Kayastha, Dhital, } \\
\text { and Smedt, 2013) }\end{array}$ \\
\hline Stream power index & $\begin{array}{l}\text { SPI was calculated using DEM in GIS. The Stream Power Index } \\
\text { (SPI) is a measure of the erosive power of flowing water. SPI } \\
\text { is calculated based upon the slope and contributing area. SPI } \\
\text { approximates locations where gullies might be more likely to } \\
\text { form on the land and cause erosion (Finlayson and Montgomery } \\
\text { 2003; Devkota, et al., 2013) }\end{array}$ \\
\hline
\end{tabular}




\begin{tabular}{|l|l|}
\hline \multicolumn{1}{|c|}{ Parameters } & Descriptions \& Justifications \\
\hline $\begin{array}{l}\text { Geomorphic } \\
\text { landscape unit }\end{array}$ & $\begin{array}{l}\text { Geomorphic landscape unit was identified based on the } \\
\text { evidence of landslides scars both old and new and footprints of } \\
\text { erosion such as highly dissected or degraded bare slope. Based } \\
\text { on the frequency and extent of the evidence of the geomorphic } \\
\text { processes, the whole study area was divided into five categories, } \\
\text { i.e., very high, high, moderate, low, or very low. The inclusion } \\
\text { of this layer in the analysis will increase the predictability of the } \\
\text { landslide susceptibility. }\end{array}$ \\
\hline Vegetation density & $\begin{array}{l}\text { Vegetation is widely accepted to stabilize slopes against } \\
\text { landslides. Therefore, obtaining information about land use and } \\
\text { land cover dynamics is for assessing landslide susceptibility. } \\
\text { Various studies suggest that the vegetation cover creates an } \\
\text { important stabilizing effect against landslides and that forested } \\
\text { areas are less prone to slope failure than other vegetation types. } \\
\text { Vegetation density is represented by the Normalized Difference } \\
\text { Vegetation Index (NDVI) using red and infrared satellite } \\
\text { imageries of the area. }\end{array}$ \\
\hline Land use/Land cover & $\begin{array}{l}\text { Land use and land cover influence the incidences of landslides } \\
\text { in various ways. Barren area or degraded area, and unscientific } \\
\text { cultivation on steep slopes are prone to landslides occurrence. } \\
\text { The role of the forest is described in the preceding row. }\end{array}$ \\
\hline
\end{tabular}

In the Landslide index method, the roles of each landslide influencing parameter were analyzed with inventoried landslides. Accordingly, landslide susceptibility weights for each parameter class were calculated. This method assumes that landslides will occur in the future in a similar condition as they occurred at present and in the past. A weightvalue for a parameter class, such as a certain lithological unit or a certain slope class, is defined as the natural logarithm of the landslide density in the class divided by the landslide density in the entire map (Van Westen, 1997):

$\ln \mathrm{W}_{\mathrm{i}}=\ln \left(\frac{\text { Densityclass }}{\text { Density map }}\right)$

Where,

$\mathrm{W}_{\mathrm{i}}=$ Calculated weight of certain factor class.

Density Class $=$ the landslide density of each factor class.

Density Map $=$ the landslide density within the entire map.

$\mathrm{Ln}=$ Natural logarithm. 
The method is based on the map crossing of the landslide map with a certain factor map. Map crossing results in a cross-table that can be used to calculate the density of landslides per factor class. Landslide susceptibility index (LSI) is determined by the summation of each factor's ratings using the equation (Lee and Pradhan, 2006).

$L S I=\sum_{i=1}^{N} W_{i}$

Where $W_{i}=$ Calculated weight to each $i$ factor

$N=$ Total number of factors

\section{Integrated erosion susceptibility}

Both indexes computed from RUSLE and Landslide susceptibility assessment are transferred into common scale $0-1$, using maximum-minimum transformation. Subsequently, overall erosion susceptibility was calculated as:

Erosion susceptibility $=\frac{\text { RSULE index }+ \text { LSI index }}{2}$

Finally, natural break classification was used in ArcGIS to show spatial variation of erosion susceptibility in the study area.

\section{Results and discussions}

\section{Overall soil loss potentiality}

The waters induced erosion included splash, sheet, rill, and gully whereas gravity caused mass movement involved slides, flow, and fall. These both phenomena are causing massive soil erosion in the Nepal Himalayas. Thus, overall erosion is estimated by integrating the estimation from RUSLE and erosion by the landslide.

Characteristics of soil erosion factors considered in RUSLE models

Five parameters contributing to soil erosion were prepared in ArcGIS environment and the annual rate was estimated using the equation-1.

\section{Rainfall erosivity factor $(\mathbf{R})$}

The amount and intensity of rainfall in a particular area determine factors in soil detachment from the earth's surface (Shrestha, 1997). The average rainfall is $537.3 \mathrm{~mm}$ with a range of $249-2454 \mathrm{~mm}$. Consequently, the estimated mean erosivity of the study 
area is $433.6 \pm 76.3 \mathrm{MJ} \mathrm{mm} / \mathrm{ha} / \mathrm{hr} /$ year (Figure-8). The higher erosivity with the mean of $730.7 \pm 96.5 \mathrm{MJ} \mathrm{mm} / \mathrm{ha} / \mathrm{hr} /$ year is concentrated in the lower segment of the valley side slopes, which includes Lumnang, Lambagar, and Phedi area. The altitude of this area is less than $3000 \mathrm{~m}$ which covers less than $5 \%$ of the total area of the basin. Similarly, about $40 \%$ of the basin is located at the altitude of $3000-5000 \mathrm{~m}$, having an average erosivity of $352.1 \pm 106.4 \mathrm{MJ} \mathrm{mm} / \mathrm{ha} / \mathrm{hr} /$ year. The land above the $5000 \mathrm{~m}$, receives the less amount of rainfall with an average of $358.9 \pm 46 \mathrm{~mm}$.

Consequently, the average erosion rate is estimated $217.3 \pm 32.7 \mathrm{MJ} \mathrm{mm} / \mathrm{ha} / \mathrm{hr} / \mathrm{year}$. The decreasing trend of rainfall with altitude in the study area can be attributed to less moisture content in the cloud in the summer and an increase in solid precipitation in winter at the higher elevation. A similar trend was found in the Chenab basin in the western Himalayas, India (Singh, Ramasastri, and Kumar, 1995) and Annapurna region of Nepal (Putkonen, 2004).

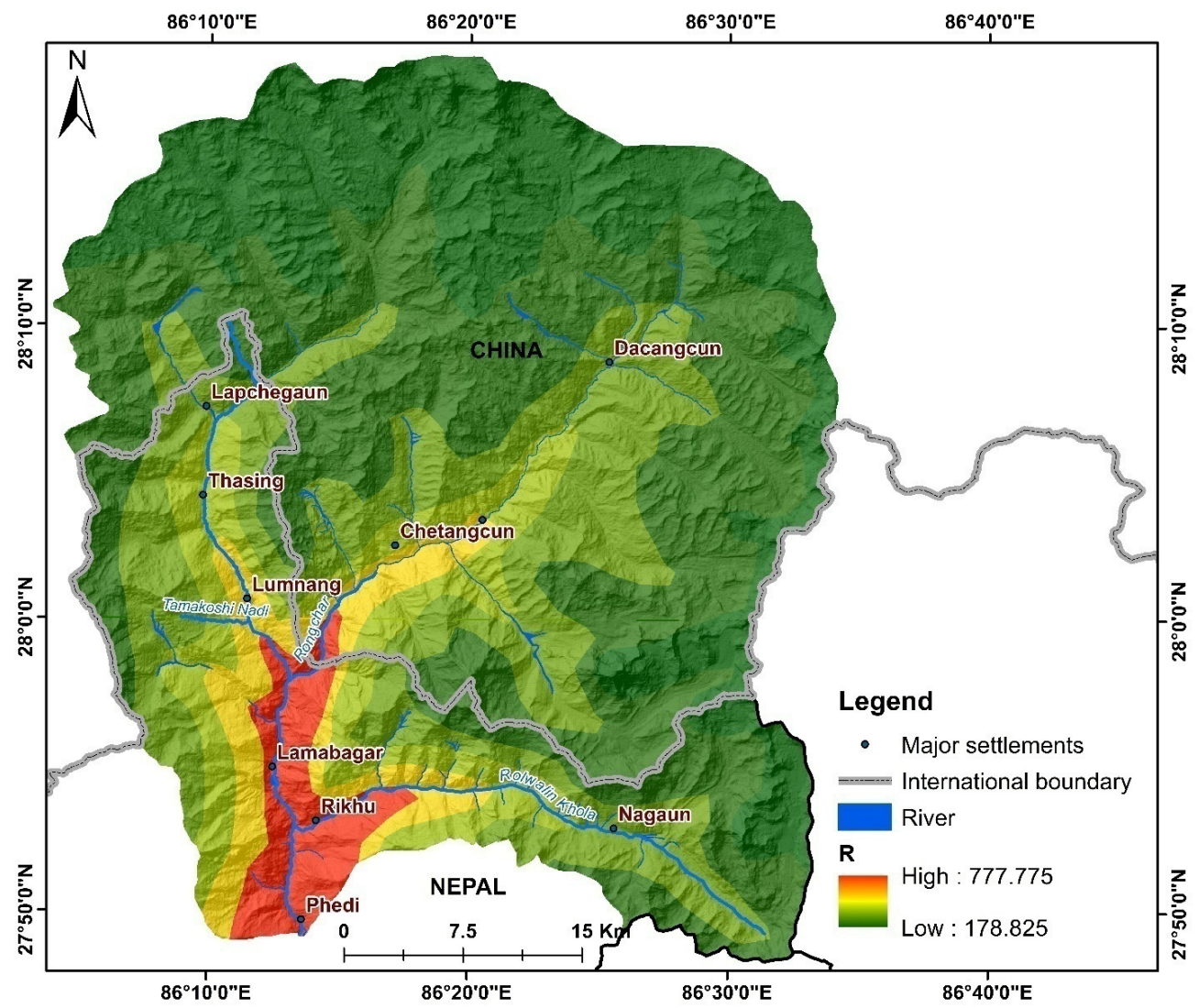

Figure 8: Rainfall erosivity factors of the Upper Tamakoshi Basin

Topographic factors (LS)

||60 | 
Normally, soil erosion is expected to increase with an increase in steepness and length of slope due to an increase in surface runoff volume and velocity (Chalise, Kumar, and Kristiansen, 2019; Holz et al, 2015). In the Tamakoshi watershed, LS ranges from 0.06 to 65.74 (Figure-9), with an average of $0.3 \pm 0.56$. More than $90 \%$ of the basin has LS value ranging from 0.06-1.1 indicate a moderate level of erosion susceptibility (Maqsoom et al., 2020). Moreover, mean LS is found as $0.63 \pm 0.82,0.43 \pm 0.62$, and $0.38 \pm 0.5$ for the altitudinal distribution of less than $3000 \mathrm{~m}, 3000-5000 \mathrm{~m}$, and more than $5000 \mathrm{~m}$, respectively. This indicates that both the ruggedness and steepness of terrain are decreasing with altitude, thereby decreasing erosion susceptibility.

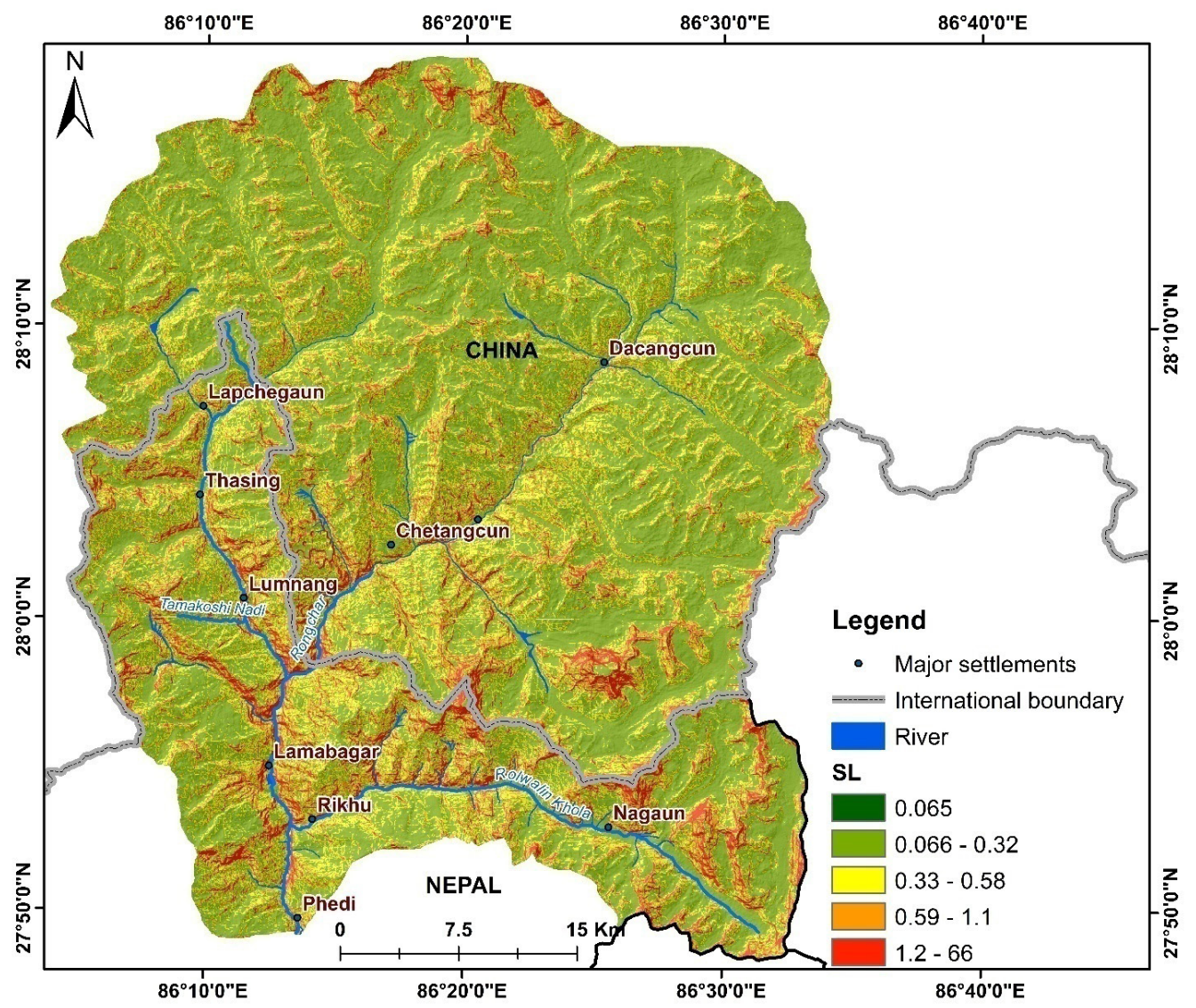

Figure 9: Distribution of topographic factor (LS)

\section{Soil erodibility factor}

The soil textures, and other soil characteristics, affect its susceptibility to erosion. Therefore, $\mathrm{K}$ factors are determined considering their inherent properties to resist the erosion stress (Table-1). The $\mathrm{K}$ factors are higher for the soil types such as Eutric 
Regosols, Humic Cambisols, Eutric Leptosols, and Haplic Luvisols, found along lower hill slope of the Tamakoshi and its tributaries. These soils normally have coarser textures and are higher susceptible to water-induced erosion (Gardner and Gerrard, 2003). Moreover, Eutric Regosols contained more than $75 \%$ of the cultivated land with an average slope of $25.6 \pm 10.7$ degrees in the study area. This condition and the low coherence of the matrix materials make the Regosols in a sloping area prone to severe erosion (Mul et al., 2015). Similarly, the average slope of Humic Cambisols is 36.1 \pm 12.6 degrees, and the area is receiving the highest rainfall in the basin with an annual average of $1514.05 \pm 418.9 \mathrm{~mm}$. The transitional stage of soil development, from young to mature on steep terrain receiving higher rainfall, this soil formation is also susceptible to intensive erosion.

The lower hill slope in and around Chentagcun, Qiase, Cangmujiancun, Long Muri, and Kaer of Tibet are composed of Haplic Luvisols, which has a mean slope of 36.5 512.9 degree and receiving an average annual rainfall of $897.4 \pm 294.6 \mathrm{~mm}$. About $32 \%$ of this soil is on a barren surface, easily eroded (Nikolic, et al., 2008). Similarly, Eutric Leptosols has a moderate level of erodibility whereas that of Gelic types of soil is less. Figure-10 shows the soil erodibility map of the study area.

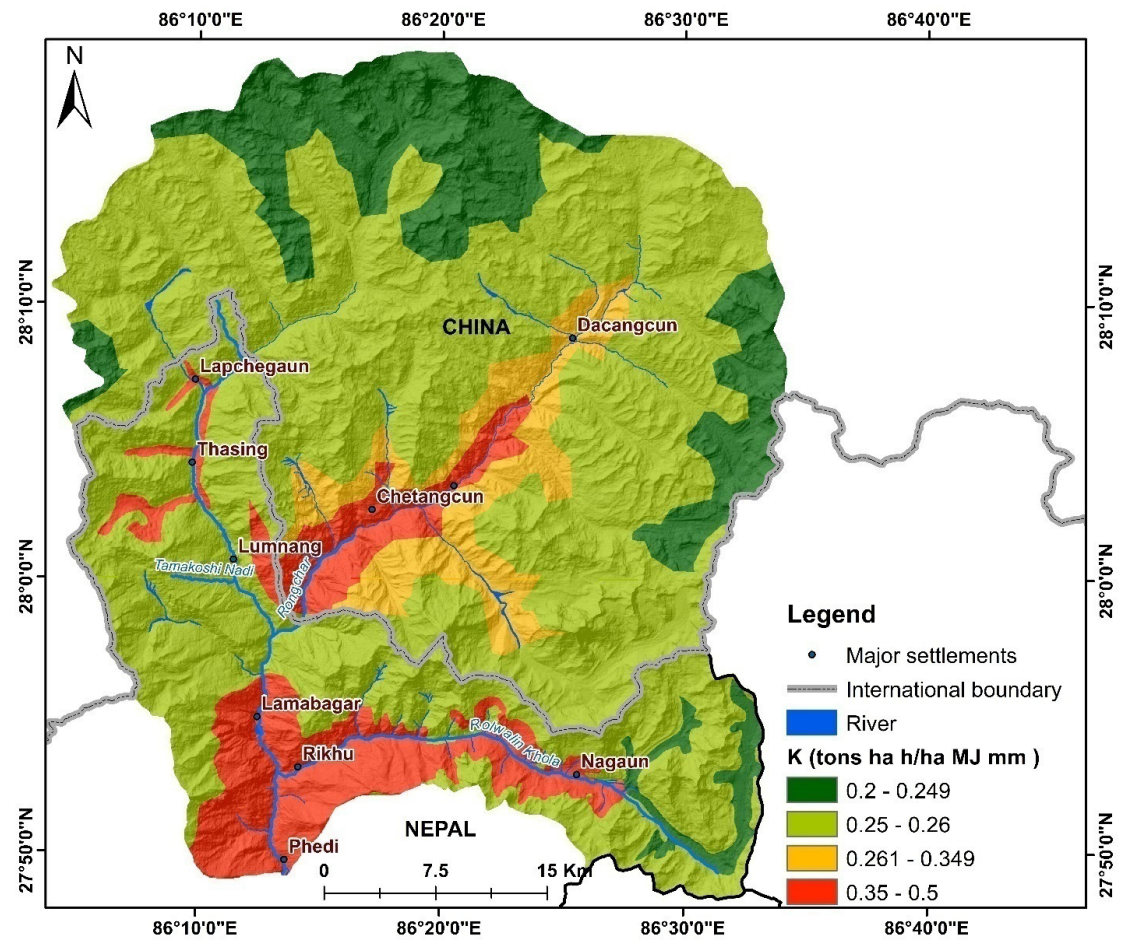

Figure 10: Soil erosibility in upper Tamaksohi basin 


\section{Cover-management factor-ratio of soil loss}

Higher the value in C factors showed the area is more susceptible to soil loss. Land cover in combination with the slope of the area plays an important role to cause or resist the slope erosion process.

Table 5: Land cover verses slope

\begin{tabular}{|l|l|l|l|l|l|l|l|l|l|l|}
\hline $\begin{array}{l}\text { Land } \\
\text { cover }\end{array}$ & $\begin{array}{l}\text { Barren } \\
\text { land }\end{array}$ & $\begin{array}{l}\text { Grass } \\
\text { land }\end{array}$ & $\begin{array}{l}\text { Glacier \& } \\
\text { Moraine }\end{array}$ & Snow & Lake & $\begin{array}{l}\text { River \& } \\
\text { riverbed }\end{array}$ & $\begin{array}{l}\text { Shrub/ } \\
\text { bushes }\end{array}$ & $\begin{array}{l}\text { Cultivated } \\
\text { land }\end{array}$ & Forest & $\begin{array}{l}\text { Built } \\
\text { up area }\end{array}$ \\
\hline $\begin{array}{l}\text { Mean } \\
\text { Slope } \\
\text { (Degree) }\end{array}$ & 31.9 & 33.0 & 17.6 & 29.4 & 12.6 & 20.4 & 35.2 & 25.6 & 34.4 & 15.5 \\
\hline $\begin{array}{l}\text { Standard } \\
\text { deviation }\end{array}$ & 14.0 & 13.1 & 11.9 & 14.5 & 10.3 & 14.5 & 12.2 & 10.7 & 11.6 & 9.2 \\
\hline
\end{tabular}

Support practice factor $(\mathrm{P})$

For this study, human intervention is low and information on support practice factor is virtually absent. Therefore, $\mathrm{P}$ factor is assigned as 1 throughout the basin.

\section{Soil loss and denudation rate in the upper Tamakoshi basin}

The RUSLE model, estimated annual soil loss of the area ranges between $0.023-101.01$ tons/ha/yr with an average of $6.8 \mathrm{tons} / \mathrm{ha} / \mathrm{yr}$ (Figure-11). Therefore, soil loss of the basin estimated by RUSLE is 1.5 million tons/yr which is equivalent to the denudation rate of $0.54 \mathrm{~mm} / \mathrm{yr}$.

The modeled soil losses also confirm the data obtained from the direct methods using field plots in the Likhu Khola valley (Likhu Khola Project, 1995). Soil erosion was monitored in field plots, under different land uses and management types. Soil loss on non-cultivated land is estimated at 11 tons/ha/year. Under rain fed cultivation, soil losses range from 2.7 to 8.2 tons/ha from 1993 to 1995 . Since the study belongs to the high Himalaya area, the erosion rate is expected higher than that estimated from the Likhu Khola valley in the Middle mountain.

Likewise, soil losses are comparatively lower (less than 10 tons/ha/yr) under land use types, such as forest, grazing land, and rice cultivation. Annual soil loss rates are maximum (up to 56 tons/ha/yr) in areas under rain fed cultivation. 


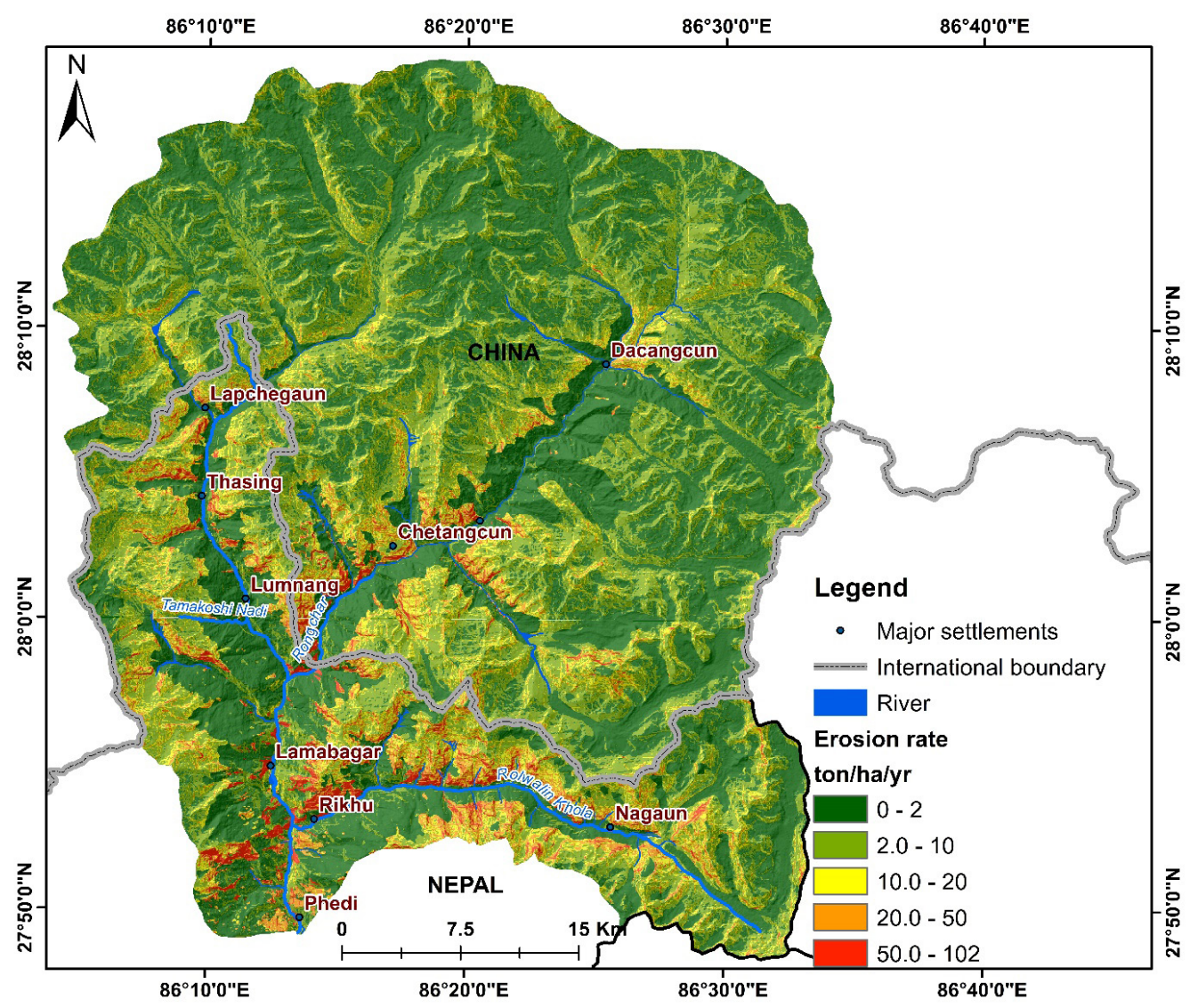

Figure 11: Erosion rate (RUSLE model)

On the other hand, the average denudation rate from landslides for the last 20 years was found as $2.8 \mathrm{~mm} / \mathrm{yr}$, whereas that of pre and post-earthquake (2015) is estimated as 1.7 $\mathrm{mm} / \mathrm{yr}$ and $3.0 \mathrm{~mm} / \mathrm{yr}$ respectively (Table 6 ). 
Table 6: Landslides and soil loss from erosion

\begin{tabular}{|l|l|l|l|l|l|l|}
\hline \multirow{2}{*}{ Period } & \multicolumn{3}{|l|}{ Soil and rock Volume (m3/yr) } & \multicolumn{3}{l|}{ Denudation rate (mm/yr) } \\
\cline { 2 - 7 } & Minimum & Maximum & Average & Minimum & Maximum & Average \\
\hline $\begin{array}{l}\text { Pre- } \\
\text { earthquake } \\
(2000-2014)\end{array}$ & 2764570.0 & 4604790.7 & 3684680.4 & 1.28 & 2.13 & 1.7 \\
\hline $\begin{array}{l}\text { Post- } \\
\text { earthquake } \\
(2015-2019)\end{array}$ & 6565369.8 & 12334507.0 & 9449938.4 & 3.0 & 5.7 & 4.4 \\
\hline $\begin{array}{l}\text { Over all } \\
(2000-2019)\end{array}$ & 4405912.4 & 7688417.5 & 6047165.0 & 2.04 & 3.56 & 2.80 \\
\hline
\end{tabular}

The landslides dominated part of the watershed receives precipitation over $2300 \mathrm{~mm}$, i.e., one of Nepal's highest precipitation regions, which makes the area susceptible to high incidences of erosion and landslide. Similarly, twenty-four-hour maximum rainfall recorded at nearby Jiri station during the last 20 years shows an increasing trend in recent decades with a peak of 71-136 mm. This rainfall intensity indicates a threshold for initiating landslides in the last two decades. Post-earthquake 24-hour maximum rainfall between 2015-2019 AD was 136, 103, 85, and $95 \mathrm{~mm}$ in the respective years (DHM, 2020). The recurrence period of these extreme rain events was of the order of $25,8,5$, and 6 years (DHM, 2020). The large volume of soil loss by landslides in the post-2015 earthquake era with subsequent aftershocks was attributed to the coupling of higher intensity rainfall with tremor shattered slopes. Since mega earthquakes-like Gorkha are rare, which may occur once in 100 years, the average denudation rate calculated for the pre-earthquake situation can be expected as a normal erosion rate in the long term.

The soil and rock loss from the landslide in the last 20 years is estimated as 7.6 million tons/year, and thus, overall slope erosion is estimated as 9.1 million tons/yr, out of which contribution by landslides is $83.7 \%$. Similarly, the overall denudation rate is estimated at $3.34 \mathrm{~mm} / \mathrm{yr}$. This contributes to the development of natural slopes of the Himalayas and the source of high sediment load in the rivers. Pioneering studies carried out by William, 1977; Caine and Mool, 1982; Kienholz et al., 1983; Fort et al., 1984; Carson, 1985 and Zimmerman et al., 1986 conclude that mass wasting is the dominant process in the evolution of natural slopes throughout much of the Nepalese Himalaya. William (1977) estimated that large landslides contributed to $31 \%$ of the sediment load of the Sapta Koshi, with a further $64 \%$ coming from small slides, surface erosion, and gullying. The enormous contribution of sediments by landslides in this basin (including the Tibetan part) can be argued that the whole basin is steep and rugged (average slope $=29.5 \pm 14.4$ degree). 
Caine and Mool (1982) gave an estimated surface lowering rate of $12 \mathrm{~mm} / \mathrm{yr}$ by landslide events. Similarly, Gabet et al., 2008, based on measurement of sediment load estimated a denudation rate which ranged from $0.2-1.1 \mathrm{~mm} / \mathrm{yr}$ in the Marsyangdi watersheds of western Nepal Himalaya, which is comparatively lower than other estimates, i.e., 2-5mm/year (Wobus et al., 2005, 2006; Hermann et al., 2010; Thiede and Ehlers, 2013; Burbank et al., 2003).

\section{Landslide susceptibility and terrain factors}

The weight or index value of the landslide on different classes of each parameter is summarized in Figure-12. Among seven parameters, the effect of all parameters on the occurrence of landslides was seen. With regards to aspects, the south and east-facing slopes demonstrated a higher likelihood of landslides. These slope aspects were more vulnerable to mass-wasting events, as they received more rainfall in a lower altitude $(<3000)$ and freeze and thaw cycle in high altitudes. Similarly, the landslides were more likely in the steeper slopes, higher elevation-relief ratio, stream power index, and erosion sensitive landscape unit. Several studies in the Himalaya have confirmed this finding (Ghimire, 2011; Dahal et al., 2008; Regmi et al., 2014). In tectonically active Himalayas, the basin with stronger relief is prone to rock falls, debris slide, debris flow, and deep-seated gravitational failures (Gabet et al., 2008; Roback et al., 2018).

In case of land cover, areas under snow, glacier-moraine, and lake have revealed negative weight, i.e., which could mean less likelihood for landslides to occur. But it should be noted that mass movement in the form of snow avalanches and snowmelt debris flow and treat-retreat of glacier and moraine, are prominent hazards in the elevation above $4500 \mathrm{~m}$. These processes were not included due to their complex nature, different process and mechanism that required a different approach to understand.

Finally, a bivariate analysis was performed in ArcGIS environment to construct a landslide susceptibility index map (Figure-12 and 13). 


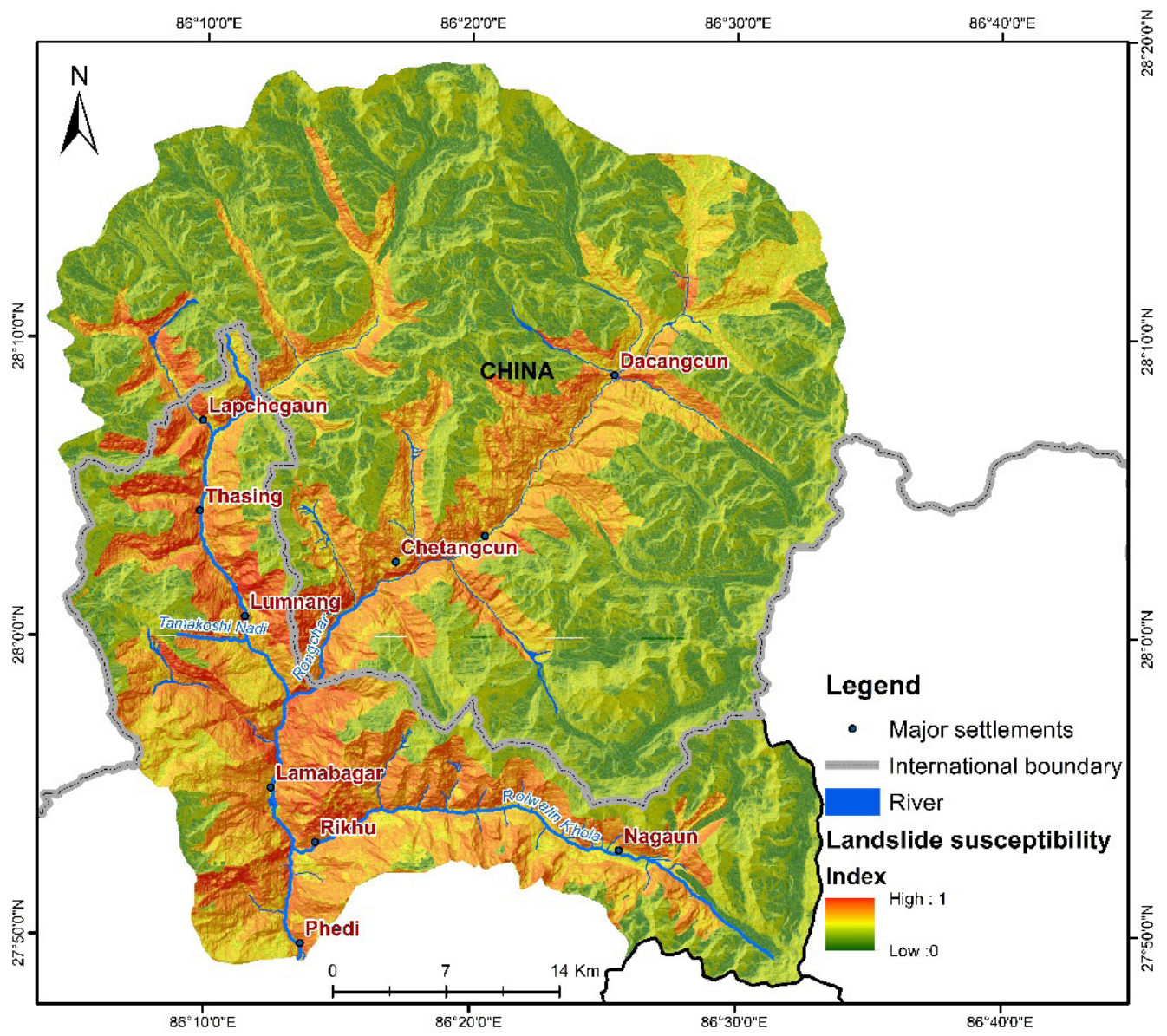

Figure 12: Landslide susceptibility map 


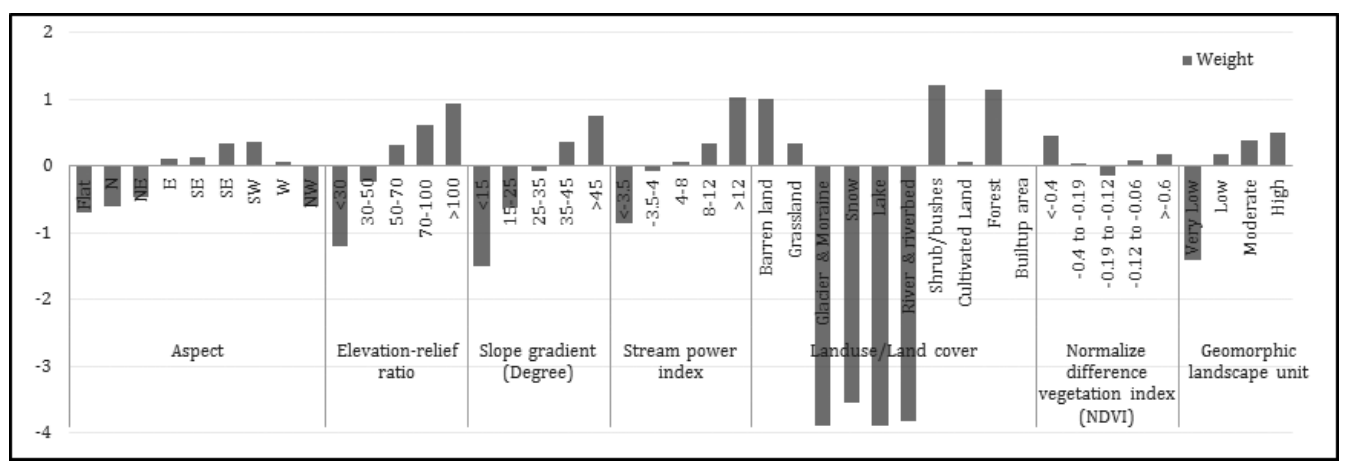

Figure 13: Calculated landslide index values (weight) for classes of the parameters

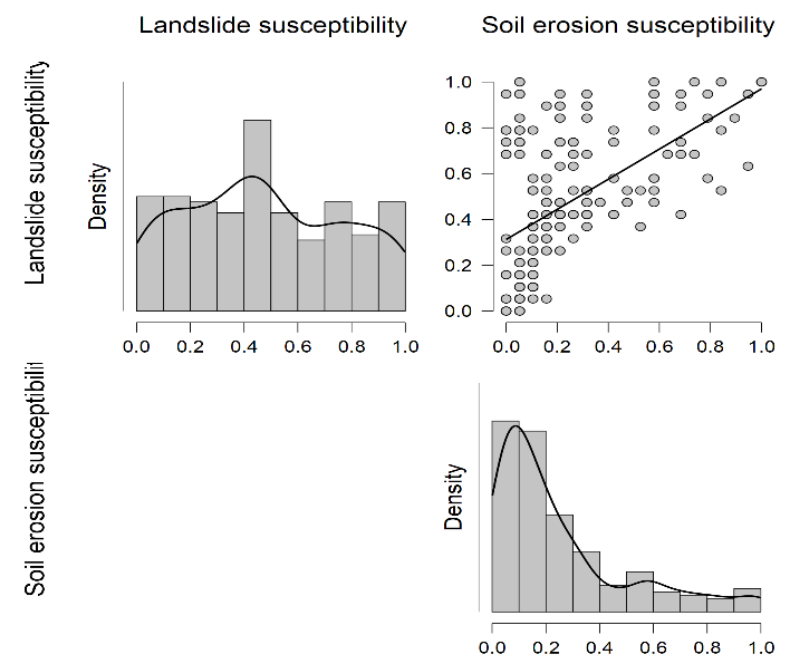

Figure 14: Distribution of landslide susceptibility (top left) and erosion susceptibility (top right) index and Relation between landslide susceptible index and soil erosion index $(n=200)$ (bottom left).

\section{Spatial correlation and integrated soil erosion, slope erosion susceptibility map}

Both RUSLE soil erosion and Landslide susceptibility indices were converted into common scale 0-1, through maximum-minimum transformation. By examining the spatial relationship between these two indices map, it was found that there exists a significant correlation between soil erosion and landslide susceptibility index map $(\mathrm{r}=0.56 ; \mathrm{p}<0.01)$ (Figure-14). This indicates that similar terrain conditions have more or less similar effects on both surface and landslide erosion. Finally, both maps were 
integrated to produce an overall slope erosion susceptibility map, which was classified into very low, low, moderate, high, and very high susceptibility zone, using Jenk's natural break method. The distribution of high susceptible slope erosion areas is represented by steep slopes, scarp slopes, high elevation relief ratio, low vegetation cover, and the corridor slopes of the V-shaped river valleys against highly deformed high-grade metaphoric rocks with a rainfall regime of 2000-2700 mm. Recent studies in the High Himalayas agree with this result (Tsou et al., 2018; Tian et al., 2020).

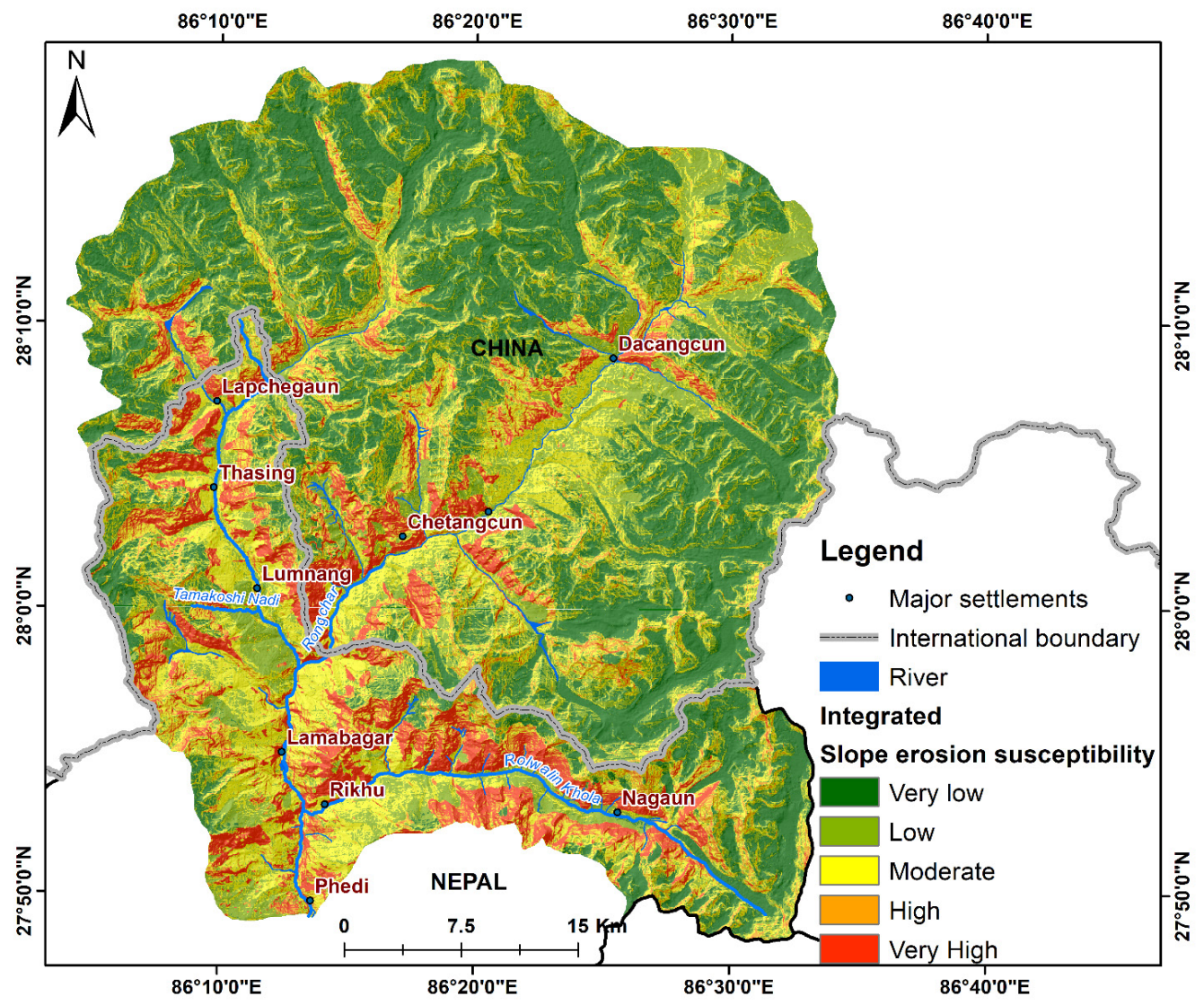

Figure 15: Integrated slope erosion susceptibility in Tamakoshi basin

\section{Conclusion}

The study has integrated the RUSLE's soil loss with soil and rocks debris erosion by landslides and finally calculated the overall slope erosion of soil loss of 9.1 million tons/ $\mathrm{yr}$ for last 20 years. This loss is equivalent to the denudation rate of $3.34 \mathrm{~mm} / \mathrm{yr}$. Out of 
this, the contribution of denudation by landslides erosion was $2.8 \mathrm{~mm} / \mathrm{yr}$. The denudation rate from the landslides after the 2015 earthquake, the five years which experienced rainfall above normal (both annual and 24-hour maximum events) was estimated to be $4.4 \mathrm{~mm} /$ year. The calculated denudation rate seems to match with the earlier estimates in the higher Himalayan areas. The contribution of landslides to total sediment yield was about $84 \%$, which implies that landslides in the hill slope development and sediment delivery are outstanding in the higher Himalayas.

Using landslide index method, the study has produced a landslides susceptibility map. The study also combined the erosion susceptibility map with the landslide susceptibility map to create an integrated slope erosion map. A significant spatial correlation exists between soil erosion and landslide susceptibility index map ( $\mathrm{r}=0.55 ; \mathrm{p}<0.001)$. This indicates that similar terrain conditions have more or less similar effects on both surface and landslide erosion. Spatially distributed integrated slope erosion map reveals the high slope erosion potential is associated with high rainfall, steep slopes, scarps, lower segment valley side slopes, and high relief. Geologically potentially high erosion is associated with highly fractured and deformed parts of high-grade metamorphic rocks, such as gneiss, quartzite, marbles, migmatite, and granitic gneiss. The study contributed to estimate the overall erosion map combining rill and sheet erosion with landslide erosion. In conclusion, the erosion issue in Higher Himalaya in Nepal seems to be more related to nature than human influence.

\section{Acknowledgments}

We are thankful to Tractebel Engineering GmbH, Germany, for providing an opportunity to conduct soil erosion assessment, which is one of the essential components of this paper. Our special gratitude goes to Mr. Klaus Moeller and Prof. Dr. Hari Krishna Shrestha for their support. We also thank Ms. Nabina Maharjan for proof reading of the manuscript and for her valuable feedback.

\section{References}

Aleotti, P., \& Chowdhury, R. (1999). Landslide hazard assessment: Summary review and new perspectives. Bulletin of Engineering Geology and the Environment, 58(1), 21-44.

Angima, S. D., Stoot, D. E., O'Neill, M. K., Ong, C. K., \& Weesies, G. A. (2003). Soil erosion prediction using RUSLE for central Kenyan highland conditions. Agriculture, Ecosystems \& Environment, 97(1-3), 295-308. 
Arnold, J. G., Srinivasan, R., Muttiah, R. S., \& Williams, J. R. (1998). Large area hydrologic modeling and assessment part I: Model development. J Am Water Resour As, 34(1), 73-89.

Ban, J. K., Yu, I., \& Jeong, S. (2016). Estimation of soil erosion using RUSLE model and GIS techniques for conservation planning from Kulekhani reservoir catchment, Nepal. J. Korean Soc. Hazard Mitig, 16(3), 323 330.

Basnet, C. B., \& Panthi, K. K. (2017). 3D in-situ stress model of upper Tamakoshi hydroelectric project area. Hydro Nepal, (21), 34-41.

Bastola, S., Seong, Y. J., Lee, S. H., Shin, Y., \& Jung, Y. (2019). Assessment of soil erosion loss by using RUSLE and GIS in the Bagmati basin of Nepal. Journal of the Korean Geo-Environmental Society, 20(3).

Batista, P. V., Davies, J., Silva, M. L., \& Quinton, J. N. (2019). On the evaluation of soil erosion models: Are we doing enough? Earth-Science Reviews, 197.

Brabb, E. E. (1985). Innovative approaches to landslide hazard mapping. Proceedings of IVth International Conference and Field Workshop in Landslides. Tokyo, Japan: Japan Landslide Society.

Burbank, D. W., Blythe, A. E., Putkonen, J., Pratt-Sitaula, B., Gabet, E., Oskin, M., \& et al. (2003). Decoupling of erosion and precipitation in the Himalayas. Nature, 652-655.

Burbank, D. W., Bookhagen, B., Gabet, E. J., \& Putkonen, J. (2012). Modern climate and erosion in the Himalaya. C.R. Geoscience, 344, 610-626.

Burbank, D. W., Leland, J., Fielding, E., Andeson, R. S., Brozovic, N., Reid, M. R., \& Duncan, C. (1996). Bedrock incision, rock uplift and threshold hillslopes in the northwestern Himalayas. Nature, 379, 505-510.

Caine, N., \& Mool, P. K. (1982). Landslides in the Kolpu Khola drainage, Middle Mountains, Nepal. Mountain Res. and Dev., 2(2), 157-173.

Carrara, A. (1983). Multivariate models for landslide hazard evaluation. Journal of the International Association for Mathematical Geology, 15, 403-426.

Carrara, A., Cardinali, M., Guzzetti, F., \& Reichenbach, P. (1995). GIS technology in mapping landslide hazard. Geographical Information Systems in Assessing Natural Hazards, 135-175.

Carson, B. (1985). Erosion and sedimentation processes in the Nepalese Himalaya. Kathmandu: International Centre for Integrated Mountain Development. 
Chalise, D., \& Kumar, L. (2020). Land use change affects water erosion in the Nepal Himalyas. PLOS ONE.

Chalise, D., Kumar, L., \& Kristiansen, P. (2019). Land degradation by soil erosion in Nepal: A review. Soil Syst., 3(12).

Chigira, M., Wang, G., \& Wu, X. (2012). 31 - Landslides induced by the Wenchuan earthquake. In J. J. Clague, Landslides: Types, Mechanisms and Modeling (pp. 383-392). British Columbia: Cambridge University Press.

Crozier, M. J. (1986). Landslides: Causes, consequences and environment. London: Croom Helm Australia Pvt. Ltd.

Cruden, D. J., \& Varnes, D. J. (1996). Landslide types and process. In A. K. Turner, \& R. L. Schuster (Eds.), Landslides: Investigations and mitigation (pp. 3675). , Washington: Transportation Research Board, US National Academy of Sciences.

Cui, K., Lu, D., \& Li, W. (2017). Comparison of landslide susceptibility mapping based on statistical index, certainty factors, weights of evidence and evidential belief function models. Geocarto International, 32(9).

Dahal, R., Hasegawa, S., Nonomura, A., Yamanaka, M., Masuda, T., \& Nishino, K. (2008). GIS-based weights-of-evidence modelling of rainfall-induced landslides in small catchments for landslide susceptibility mapping. Environmental Geology, 54(2), 311-324.

de Vente, J., Poesen, J., Verstraeten, G., Govers, G., Vanmaercke, M., Rompaey, A. V., Boix-Fayos, C. (2014). Corrigendum to "Predicting soil erosion and sediment yield at regional scales: Where do we stand?". Earth-Science Reviews, 133, 16-29.

Densmore, A. L., \& Hovius, N. (2000). Topographic fingerprints of bedrock landslides. Geology, 28(4), 371-374.

Devkota, K. C., Regmi, A. D., Pourghasemi, H. R., Yoshida, K., Pradhan, B., Ryu, I. C., ... Althuwaynee , O. F. (2013). Landslide susceptibility mapping using certainty factor, index of entropy and logistic regression models in GIS and their comparison at Mugling-Narayanghat road section in Nepal Himalaya. Natural Hazards, 65, 135-165.

Dhital, M. R. (2015). Geology of the Nepal Himalaya, Regional Perspective of the Classic Collided Orogen. (R. Oberhänsli, M. J. de Wit, \& F. M. Roure, Eds.) Springer. 
DHM. (2020). Meteorological Forecasting Division: Jiri. Retrieved from http://mfd. wscada.net/city?id=39

Eeckhaut, M. V., Hervás, J., Jaedicke, C., Malet, J., Montanarella, L., \& Nadim, F. (2012). Statistical modelling of Europe-wide landslide susceptibility using limited landslide inventory data. Landslides, 9, 357-369.

Felicísimo, Á. M., Cuartero, A., Remondo, J., \& Quirós , E. (2013). Mapping landslide susceptibility with logistic regression, multiple adaptive regression splines, classification and regression trees, and maximum entropy methods: a comparative study. Landslides, 10, 175-189.

Fick, S. E., \& Hijmans, R. J. (2017). WorldClim 2: new $1 \mathrm{~km}$ spatial resolution climate surfaces for global land areas. International Journal of Climatolog, 37(12), $4302-4315$.

Finlayson, D. P., \& Montgomery, D. R. (2003). Modeling large-scale fluvial erosion in geographic information systems. Geomorphology, 53(1-2), 147-164.

Formetta, G., Capparelli, G., \& Versace, P. (2016). Evaluating performance of simplified physically based models for shallow landslide susceptibility. Hydrol. Earth Syst. Sci., 20, 4585-4603.

Fort, M. B. (1987). Sporadic morphogenesis in a continental subduction setting: an example from the nnapurna Range, Nepal Himalaya. Z. Geomorph. N.F., Suppl.-Bd, 63, 9-36.

Gabet, E. J., Burbank, D. W., Pratt-Sitaula, B., Putkonen, J., \& Bookhagen, B. (2008). Modern erosion rates in the High Himalayas of Nepal. Earth and Planetary Science Letters, 267(3-4), 482-494.

Gabet, E. J., Burbank, D. W., Putkonen, J. K., Pratt-Sitaula, B. A., \& Ojha, T. (2004). Rainfall thresholds for landsliding in the Himalayas of Nepal. Geomorphology, 63(3-4), 131-143.

Ganasri, P. B., \& Ramesh, H. (2016). Assessment of soil erosion by RUSLE model using remote sensing and GIS - A case study of Nethravathi Basin. Geoscience Frontiers, 953-961.

Gardner, R. M., \& Gerrard, A. J. (2003). Runoff and soil erosion on cultivated rainfed terraces in the Middle Hills of Nepal. Applied Geography, 23, 23-45.

Ghimire, M. (2001). Geo-hydrological hazard and risk zonation of Banganga watershed using GIS and remote. J Nepal Geol Soc, 23, 99-110. 
Niroj Timalsina, Motilal Ghimire/ Assessment of denudation ...Vol. 14: 41-80, 2021

Ghimire, M. (2011). Landslide occurrence and its relation with terrain factors in the Siwalik Hills, Nepal: case study of susceptibility assessment in three basins. Natural Hazards, 56, 299-320.

Ghimire, M., \& Timalsina, N. (2020). Landslide Distribution and Processes in the Hills of Central Nepal:Geomorphic and Statistical Approach to Susceptibility Assessment. Journal of Geosciences and Environment Protection (GEP), In press.

Ghimire, S. K., Higaki, D., \& Bhattarai, T. P. (2013). Estimation of soil erosion rates and eroded sediment in a degraded catchment of the Siwalik Hills, Nepal. Land, 2, 370-391.

Guzzetti, F., Carrara, A., Cardinali, M., \& Reichenbach, P. (1999). Landslide hazard evaluation: A review of current techniques and their application in a multi-scale study, Central Italy. Geomorphology, 31(1-4), 181-216.

Guzzetti, F., Reichenbach, P., Cardinali, M., Galli, M., \& Ardizzone, F. (2005). Probabilistic landslide hazard assessment at the basin scale. Geomorphology, 72, 272-299.

Hagen, T. (1968). Report on the Geological survey of Nepal, 2. Geology of Thak khola including adjacent areas. Denkschrifiten der Schweizerschennaturforschen Gesellschaft.

Herman, F., Copeland, P., Avouac, J.P., Bollinger, L., Mahéo, G., Fort, P. L., Henery, P. (2010). Exhumation, crustal deformation, and thermal structure of the Nepal Himalaya derived from the inversion of thermochronological and thermobarometric data and modeling of the topography. Journal of Geophysical Research, 115.

Holz, D. J., Williard, K. W., Edwards, P. J., \& Schoonover, J. E. (2015). Soil erosion in humid regions: A review. J. Contemp., 48-59.

Hovius, N., Stark, C. P., \& Allen, P. A. (1997). Sediment flux from a mountain belt derived by landslide mapping. Geology, 25(3), 231-234.

Hussain, I., \& Misra, K. U. (2018). Soil loss estimation in GIS framework: A case study in Champabati watershed. International Journal of Innovative Research in Advanced Engineering (IJIRAE), 5(5), 187-196.

Jain, K. S., Kumar, S., \& Varghese, J. (2001). Estimation of soil erosion for a Himalayan watershed using GIS technique. Water Resources Management, 15, 41-54. 
Jetten, V., de Roo, A., \& Favis-Mortlock, D. (1999). Evaluation of field-scale and catchment-scale soil erosion models. CATENA, 37(3-4), 521-541.

Kayastha, P., Dhital, M. R., \& Smedt, F. D. (2013). Evaluation of the consistency of landslide susceptibility mapping: a case study from the Kankai watershed in east Nepal. Landslides, 10, 785-799.

Kienholz, H., Hafner, H., Schnieder, S., \& Tamrakar, R. (1983). Mountain hazards mapping in Nepal's Middle Mountains: maps of land use and geomorphic damages (Kathmandu-Kakani area). Mountain Res. and Dev., 3(3), 195-220.

Koirala, P., Thakuri, S., Joshi, S., \& Chauhan, R. (2019). Estimation of soil erosion in Nepal using a RUSLE modeling and geospatial tool. Geosciences, 9(147). doi:http://dx.doi.org/10.3390/geosciences9040147

Korup, O., Densmore, A. L., \& Schlunegger, F. (2010). The role of landslides in mountain range evolution. Geomorphology, 120(1-2), 77-90.

Kouli, M., Soupios, P., \& Vallianatos, F. (2009). Soil erosion prediction using the Revised Universal Soil Loss Equation (RUSLE) in a GIS framework, Chania, Northwestern Crete, Greece. Environmental Geology, 57, 483-497.

Larsen, I. J., Montgomery, D. R., \& Korup, O. (2010). Landslide erosion controlled by hillslope material. Nature Geosicence, 3, 247-251.

Lee, S., \& Pradhan, B. (2006). Probabilistic landslide hazards and risk mapping on Penang Island, Malaysia,. Earth System Science, 115(6), 661-672.

Leibundgut, G., Sudmeier-Rieux, K., Devkota, S., Jaboyedoff, M., Derron, M., Penna, I., \& Nguyen, L. (2016). Rural earthen roads impact assessment in Phewa watershed, Western region, Nepal. Geoenvironmental Disasters, 3(13).

Li, D., Nian, T., Wu, H., Wang, F., \& Zheng, L. (2020). A predictive model for the geometry of landslide dams in V-shaped valleys. Bulletin of Engineering Geology and the Environment, 4595-4608.

Maqsoom, A., Aslam, B., Hassan, U., Kazmi, Z. A., Sodangi, M., Tufail, R. F., \& Farroq, D. (2020). Geospatial Assessment of Soil Erosion Intensity and Sediment Yield Using the Revised Universal Soil Loss Equation (RUSLE) Model. International Journal of Geo-Information, 9(356). doi:10.3390/ijgi9060356

Marc, O., Behling, R., Andermann, C., Turowski, J. M., Illien, L., Roessner, S., \& Hovius, N. (2019). Long-term erosion of the Nepal Himalayas by bedrock landsliding: the role of monsoons, earthquakes and giant landslides. Earth Surf. Dynam, 7, 107-128. 
McAdoo, B. G., Quak, M., Gnyawali, K. R., Adhikari, B. R., Devkota, S., Rajbhandari, P. L., \& Sudmeier-Rieux, K. (2018). Roads and landslides in Nepal: how development affects environmental risk. Nat. Hazards Earth Syst. Sci., 32033210.

Montgomery, D. R., \& Dietrich, W. E. (1994). A physically based model for the topographic control of shallow landsliding. Water Resour. Res., 30(4), 11531171.

Morgan, R. C., Quinton, J. N., Smith, R. E., Govers, G., Posen, J. A., Auerswald, K., Styczen, M. E. (1998). The European soil erosion model (EUROSEM): A dynamic apprach for predicting sediment transport form field and small catchments. Earth Surf. Process. Landforms, 23, 527-544.

Morgan, R. P., Morgan, D. D., \& Finney, H. J. (1984). A predictive model for the assessment of soil erosion risk. Journal of Agricultural Engineering Research, $30,245-253$.

Morin, G. P., Lavé, J., France-Lanord, C., Rigaudier, T., Gajurel, A. P., \& Sinha, R. (2018). Annual sediment transport dynamics in the Narayani basin, central Nepal: Assessing the impacts of erosion processes in the annual sediment budget. Journal of Geophysical Research: Earth Surface, 2341-2376.

Mul, M., Obuobie, E., Appoh, R., Kankam-Yeboah, K., Bekoe-Obeng, E., Amisigo, B., McCartney, M. (2015). Water resources assessment of the Volta river basin. Colombo, Sri Lanka: IWMI Working Paper.

NEA.(2020,11,15). Nepal electricity authority. Retrieved from Tenders/Prequalification: https://www.nea.org.np/tender_prequalification?page $=2$

Nearing, M. A., Ascough, L. D., \& Chaves, H. M. (1989). WEPP Model sensitivity analysis (Chapter 14). In L. J. Lane, \& M. A. Nearing, USDA-Water Erosion Prediction Project: Hillslope Profile Model Documentation. West Lafayette, Indiana: USDA-ARS National Erosion Research Laboratory .

Nepal, N., Chen, J., Chen, H., Wang, X., \& Sharma, T. P. (2019). Assessment of landslide susceptibility along the Araniko highway in Poiqu/Bhote Koshi/Sun Koshi Watershed, Nepal Himalaya. Progress in Disaster Science, 3.

Nikolic, N., Schultze-Kraft, R., Nikolic, M., Bocker, R., \& Holz, I. (2008). Land degradation on barren hills: A case study in northeast Vietnam. Environmental Management, 42, 19-36.

Pachauri, A. K., Gupta, P. V., \& Chander, R. (1998). Landslide zoning in a part of the Garhwal Himalayas. Environmental Geology, 36, 325-334. 
Panthi, K. K., \& Basnet, C. B. (2019). Evaluation of earthquake impact on magnitude of the minimum principal stress along a shotcrete lined pressure tunnel in Nepal. Journal of Rock Mechanics and Geotechnical Engineering, 11, 920-934.

Piacentini, D., Troiani, F., Soldati, M., Notarnicola, C., Savelli, D., Schneiderbauer, S., \& Strada, C. (2012). Statistical analysis for assessing shallow-landslide susceptibility in South Tyrol (south-eastern Alps, Italy). Geomorphology, 151152, 196-206.

Pradhan, A. M., \& Kim, Y.-T. (2014). Relative effect method of landslide susceptibility zonation in weathered granite soil: a case study in Deokjeok-riCreek, South Korea. Nat Hazards, 72, 1189-1217.

Putkonen, J. K. (2004). Continuous snow and rain data at 500 to $4400 \mathrm{~m}$ altitude near Annapurna, Nepal, 1999-2001. Arctic, Antarctic, and Alpine Research, 36(2), 244-248.

Regmi, A. D., Devkota, K. C., Yoshida, K., Pradhan, B., Pourghasemi, H. R., Kumamoto , T., \& Akgun, A. (2014). Application of frequency ratio, statistical index, and weights-of-evidence models and their comparison in landslide susceptibility mapping in Central Nepal Himalaya. Arabian Journal of Geosciences, 7, 725742.

Reichenbach, P., Rossi, M., Malamud, B. D., Mihir, M., \& Guzzeti, F. (2018). A review of statistically-based landslide susceptibility models. Earth-Science Reviews, $180,60-91$.

Renard, K. G., Foster, G. R., Weesies, G. A., \& Porter, J. P. (1991). RUSLE: Revised universal soil loss equation. Journal of Soil and Water Conservation, 46(1), 30-33.

Renard, K. G., Foster, G. R., Weesies, G. A., McColl, D. K., \& Yoder, D. C. (1997). Predicting soil erosion by water: a guide to conservation planning with the Revised Universal Soil Loss Equation (RUSLE). Agriculture Handbook No. 703, USDA-ARS.

Schelling, D. (1987). The geology of the Rolwaling-Lapchi Kang Himalayas, eastcentral Nepal: Preliminary findings. J Nepal Geol Soc, 4, 1-19.

Schuster, R. L., \& Highland, L. M. (2007). Overview of the effects of mass wasting on the natural environment. Environmental \& Engineering Geoscience, XIII(1), $25-44$.

Selby, M. J. (1993). Hill slope materials and processes. Oxford: Oxford University Press. 
Shrestha, D. P. (1997). Assessment of soil erosion in the Nepalese Himalaya, A case study in Likhu khola valley, middle mountain Region. Land Husbandry, 2(1), 59-80.

Shrestha, S., Bajracharya, A. R., \& Babel, M. S. (2016). Assessment of risks due to climate change for the UpperTamakoshi Hydropower Project in Nepal. Climate Risk Management, 14, 27-41.

Shrestha, S., Kang, T.-S., \& Choi, J. C. (2018). Assessment of co-seismic landslide susceptibility using LR and ANCOVA in Barpak region, Nepal. J. Earth Syst. Sci., 127(38).

Sigh, J., \& Singh, O. (2020). Assessing rainfall erosivity and erosivity density over a western Himalayan catchment, India. Journal of Earth System Science volume, 129.

Singh, P., Ramasastri, K. S., \& Kumar, N. (1995). Topographical influence on precipitation distribution in different ranges of western Himalayas. Nordic Hydrology, 26, 259-284.

Struck, M., Andermann, C., Hovius, N., Korup, O., Turowski, J. M., Bista, R., Dahal, R. K. (2015). Monsoonal hillslope processes determine grain size-specific suspended sediment fluxes in a trans-Himalayan river. Geophysical Research Letter, 42(7), 2302-2308.

Teng, H., Liang, Z., Chen, S., Liu, Y., Rossel, R. A., Chappell, A., Shi, Z. (2018). Current and future assessments of soil erosion by water on the Tibetan Plateau based on RUSLE and CMIP5 climate models. Science of the Total Environment, 635, 673-686.

Thapa, P. (2020). Spatial estimation of soil erosion using RUSLE modeling: a case study of Dolakha district, Nepal. Environ Syst Res, 9(15).

Thiede, R. C., \& Ehlers, T. A. (2013). Erratum to "Large spatial and temporal variations in Himalayan". Earth Planet. Sci. Lett., 371-372.

Thiede, R. C., Bookhagen, B., Arrowmith, J. R., Sobel, E. R., \& Strecker, M. R. (2004). Climatic control on rapid exhumation along the Southern Himalayan Front. Earth and Planetary Science Letters, 222(3-4), 791-806.

Tian, Y., Owen, L. A., Xu, C., Ma, S., Li, K., Xu, X., Maharjan, S. B. (2020). Landslide development within 3 years after the $2015 \mathrm{Mw} 7.8$ Gorkha earthquake, Nepal. Landslides, 17, 1251-1267. 
Tsou, C.-Y., Chigira, M., Higaki, D., Sato, G., Yagi,, H., Sato, H. P., . Yatagai, A. (2018). Topographic and geologic controls on landslides induced by the 2015 Gorkha earthquake and its aftershocks: an example from the Trishuli Valley, central Nepal. Landslides, 15, 953-965.

Uddin, K., Martin, M. A., \& Maharjan, S. (2018). Assessment of land cover change and its impact on changes in soil erosion risk in Nepal. Sustainability, 10(12).

USDA. (2000). Predicting soil erosion by water: A guide to conservation planning with the Revised Universila Soil Loss Equation (RUSLE). (K. G. Renard, G. R. Foster, G. A. Weesies, D. K. McCool, \& D. C. Yoder, Eds.) Washington: Agriculture Reserach Service, United States Department of Agriculture.

Van Rompaey, A. J., Vieillefont, V., Jones, R. J., Montanarella, L., Verstraeten, G., Bazzoffi, P., . . . Poesen, J. (2003). Validation of soil erosion estimates at European scale. European Soil Bureau Research Report No.13, EUR 20827 $E N$. Luxembourg: European Communities.

Van Westen , C. J. (2000). The modelling of landslide hazards using GIS. Surveys in Geophysics, 21, 241-255.

Van Westen, C. (1997). Statistical landslide hazard analysis ILWIS 2.1 for Windows application guide. Enschede: ITC Publication.

Varnes, D. (1984). IAEG Commission on landslides (1984) Landslide hazard zonation-A review of principles and practices (Vol. 3). Paris: UNESCO, Natural Hazard Series.

Veeranarayana, B., Raju, R. P., \& Wuletaw, M. (2019). Integrated remote sensing and GIS-based Universal Soil Loss Equation for soil erosion estimation in the Megech River catchment, Tana Lake Sub-basin, northwestern Ethiopia. American Journal of Geographic Information System, 8(4), 141-157.

Williams, V. S. (1977). Neotectonic implications of the alluvial record in the Sapta Kosi drainage basin, Nepalese Himalayas. Seattle, USA: PhD Thesis, Dept. of Geology, Univ. of Washington.

Wischeimer, W. H., \& Smith, D. D. (1978). Predicting rainfall erosion loses - a guide to conservation planning. Washington: USDA: Agriculture Handbook No. 537.

Wobus, C. W., Whipple, K. X., \& Hodges, K. V. (2006). Neotectonics of the central Nepalese Himalaya: Constraints from geomorphology, detrital 40Ar/39Ar thermochronology, and thermal modeling. Techtonics, 25. 
Wobus, C., Heimsath, A., Whipple, K., \& Hodges, K. (2005). Active out-of-sequence thrust faulting in the central Nepalese Himalaya. Nature, 434, 1008-1011.

Yang, G., \& Gao, Y. (2018). Changes in physical properties of soil on forest floors as a result of landslides caused by the Wenchuan earthquake. In N. Timalsina, N. Agrawal, N. Bhattarai, J. Chand, T. Bhandari, \& S. Amatya (Ed.), BMUBICIMOD expert consultation workshop on Hindu Kush Himalayan Mountain Soils (pp. 63-69). Kathmandu: International Centre for Integrated Mountain Development (ICIMOD).

Zimmerman, M., Bischel, M., \& Kienholz, H. (1986). Mountain hazards mapping in the Khumbu Himal, Nepal, with a prototype map, scale 1:50,000. Mountain Res. and Dev, 6(1), 29-40. 